\title{
Evaluation of water vapour assimilation in the tropical upper troposphere and lower stratosphere by a chemical transport model
}

\author{
Swagata Payra ${ }^{1,2, a}$, Philippe Ricaud ${ }^{1}$, Rachid Abida ${ }^{1}$, Laaziz El Amraoui ${ }^{1}$, Jean-Luc Attié ${ }^{1,2}$, Emmanuel Rivière $^{3}$, \\ Fabien Carminati ${ }^{4}$, and Thomas von Clarmann ${ }^{5}$ \\ ${ }^{1}$ CNRM, Météo-France, CNRS UMR3589, Toulouse, France \\ ${ }^{2}$ Laboratoire d'Aérologie, Université de Toulouse, CNRS UMR5560, Toulouse, France \\ ${ }^{3}$ GSMA, CNRS, Université Champagne Ardennes, Reims, France \\ ${ }^{4}$ Met Office, Exeter, UK \\ ${ }^{5}$ KIT, Karlsruhe, Germany \\ anow at: Birla Institute of Technology Mesra, Jaipur Campus, Rajasthan, India
}

Correspondence to: Philippe Ricaud (philippe.ricaud@meteo.fr)

Received: 12 February 2016 - Published in Atmos. Meas. Tech. Discuss.: 17 March 2016

Revised: 27 July 2016 - Accepted: 16 August 2016 - Published: 6 September 2016

\begin{abstract}
The present analysis deals with one of the most debated aspects of the studies on the upper troposphere/lower stratosphere (UTLS), namely the budget of water vapour $\left(\mathrm{H}_{2} \mathrm{O}\right)$ at the tropical tropopause. Within the French project "Multiscale water budget in the upper troposphere and lower stratosphere in the TROpics" (TRO-pico), a global-scale analysis has been set up based on space-borne observations, models and assimilation techniques. The MOCAGEVALENTINA assimilation tool has been used to assimilate the Aura Microwave Limb Sounder (MLS) version $3.3 \mathrm{H}_{2} \mathrm{O}$ measurements within the 316-5 hPa range from August 2011 to March 2013 with an assimilation window of $1 \mathrm{~h}$. Diagnostics based on observations minus analysis and forecast are developed to assess the quality of the assimilated $\mathrm{H}_{2} \mathrm{O}$ fields. Comparison with an independent source of $\mathrm{H}_{2} \mathrm{O}$ measurements in the UTLS based on the space-borne Michelson Interferometer for Passive Atmospheric Sounding (MIPAS) observations and with meteorological ARPEGE analyses is also shown. Sensitivity studies of the analysed fields have been performed by (1) considering periods when no MLS measurements are available and (2) using $\mathrm{H}_{2} \mathrm{O}$ data from another MLS version (4.2). The studies have been performed within three different spaces in time and space coincidences with MLS (hereafter referred to as MLS space) and MIPAS (MIPAS space) observations and with the model
\end{abstract}

(model space) outputs and at three different levels: $121 \mathrm{hPa}$ (upper troposphere), $100 \mathrm{hPa}$ (tropopause) and $68 \mathrm{hPa}$ (lower stratosphere) in January and February 2012. In the MLS space, the analyses behave consistently with the MLS observations from the upper troposphere to the lower stratosphere. In the model space, the analyses are wetter than the reference atmosphere as represented by ARPEGE and MLS in the upper troposphere $(121 \mathrm{hPa})$ and around the tropopause $(100 \mathrm{hPa})$, but are consistent with MLS and MIPAS in the lower stratosphere $(68 \mathrm{hPa})$. In the MIPAS space, the sensitivity and the vertical resolution of the MIPAS data set at 121 and $100 \mathrm{hPa}$ prevent assessment of the behaviour of the analyses at 121 and $100 \mathrm{hPa}$, particularly over intense convective areas as the South American, the African and the Maritime continents but, in the lower stratosphere $(68 \mathrm{hPa})$, the analyses are very consistent with MIPAS. Sensitivity studies show the improvement on the $\mathrm{H}_{2} \mathrm{O}$ analyses in the tropical UTLS when assimilating space-borne measurements of better quality, particularly over the convective areas. 


\section{Introduction}

Water is constantly cycling through the atmosphere. It evaporates from the Earth's surface and rises on warm updrafts into the atmosphere. Then it condenses into clouds, is blown by the wind and then falls back to the Earth's surface as rain or snow. This cycle is one important way to transfer the heat and energy from the surface of the Earth to the atmosphere, and to transport it from one place to another on the globe. Water vapour $\left(\mathrm{H}_{2} \mathrm{O}\right)$ is also one of the dominant greenhouse gases in the Earth's atmosphere. Unlike some other greenhouse gases, the contribution of anthropogenic sources to the atmospheric water vapour is negligible (IPCC, 2007). The increase in water vapour occurs because the climate is warming, and the increase then contributes to further warming. This process is referred to as positive feedback. The effect of water vapour as a greenhouse gas on climate change is a key parameter due to its positive feedback on the Earth radiative budget. The concentration of water vapour in the atmosphere ranges from $3 \%$ of volume in wet tropical areas to a few parts per million by volume (ppmv) in the stratosphere. Water vapour mixing ratio in the lower stratosphere is generally very low (2.5-5.3 ppmv) (e.g. see reference list of Randel and Jensen, 2013).

Brewer (1949) postulated that the observed stratospheric air must have passed through the cold tropopause region observed over the tropics. The evolution of $\mathrm{H}_{2} \mathrm{O}$ in the upper troposphere and lower stratosphere (UTLS) is still not well understood, irrespective of numerous space- and balloonborne data now available. One of the challenging regions is the tropical tropopause layer (TTL). The layer is maintained by a complex interplay between large- and small-scale circulation patterns, deep convection, clouds and radiation (Randel and Jensen, 2013). $\mathrm{H}_{2} \mathrm{O}$ is also a key constituent in atmospheric chemistry. It is the source of hydroxyl $(\mathrm{OH})$, which controls the lifetime of shorter lived pollutants, tropospheric and stratospheric ozone and other longer lived greenhouse gases such as methane (Seinfeld and Pandis, 2006). Furthermore, $\mathrm{H}_{2} \mathrm{O}$ has an important influence on stratospheric chemistry through its ability to form ice, which offers a surface for heterogeneous chemical reactions involved in the destruction of stratospheric $\mathrm{O}_{3}$ via polar stratospheric clouds. It is noteworthy that despite the importance of water vapour, there seems to be only little skill in representing water vapour distributions in current chemistry-climate models, especially in the extratropical UTLS (Hegglin et al., 2010), as well as in climate models such as those used for the International Panel on Climate Change (IPCC) climate assessments (Jiang et al., 2012) and reanalyses (Jiang et al., 2010) in these regions. Combining models and measurements together to understand the interannual and long-term behaviour of stratospheric water vapour, even in the lower stratosphere, as presented in Hegglin et al. (2014), can help to characterise biases in observations and also the physical processes responsible for the long-term trends in water vapour.
The lack of progress in representing UTLS water vapour in models may partially be explained by inconclusive observational records to which the models are compared (SPARC CCMVal, 2010). It is not easy to accurately measure water vapour in the TTL, and satellite measurements, as well as in situ correlative data, have been shown to exhibit large absolute differences (SPARC WAVAS, 2000). In particular, the current lack of an accepted standard from in situ correlative data precludes a conclusive assessment of the performance of available satellite water vapour measurements (see Weinstock et al., 2009). To cope with this issue, the Global Climate Observing System (GCOS) Reference Upper-Air Network (GRUAN) international reference observing network has been designed to fill an important gap in the current global observing system, providing long-term, high-quality climate data records (including $\mathrm{H}_{2} \mathrm{O}$ ) from the surface, through the troposphere and into the stratosphere (see e.g. http://www.dwd.de/EN/research/ international_programme/gruan/home.html).

Around the tropical tropopause, large vertical gradients in $\mathrm{H}_{2} \mathrm{O}$ and interplay of transport processes between troposphere and stratosphere, mainly due to rapid change in $\mathrm{H}_{2} \mathrm{O}$ by deep convection reaching the uppermost troposphere/lowermost stratosphere, are highly challenging for an accurate representation of $\mathrm{H}_{2} \mathrm{O}$ in global models. The most advanced numerical weather prediction (NWP) models use sophisticated data assimilation systems to better represent $\mathrm{H}_{2} \mathrm{O}$ in the UTLS based on direct (e.g. radiosonde) and indirect (e.g. satellite radiance) observations. For instance, at the European Centre for Medium-range Forecasts (ECMWF), state-of-the-art assimilation systems are operationally used to provide some of the best forecasts, analyses and reanalyses among NWP centres around the world (http://apps.ecmwf.int/wmolcdnv/).

Recently, Kunz et al. (2014) carried out a comprehensive assessment of the UTLS $\mathrm{H}_{2} \mathrm{O}$ in the most recent ECMWF analyses and reanalyses. The authors compared the operational analysis and ERA-Interim reanalysis data sets to a 10year climatology of $\mathrm{H}_{2} \mathrm{O}$ measurements in the UTLS from the Fast In Situ Stratospheric Hygrometer (FISH, Zöger et al., 1999). FISH instruments have been used between 2001 and 2011 in 10 international airborne campaigns from polar regions to the tropics, including the Tropical Convection, Cirrus and Nitrogen Oxides Experiment (TROCCINOX) campaign in 2005, which was specifically dedicated to the study of deep tropical convection (Schiller et al., 2009).

ERA-Interim reanalyses benefit from the $12 \mathrm{~h}$ sequential 4-D-Var data assimilation scheme at T255 spectral resolution $(80 \mathrm{~km})$ and 60 vertical hybrid levels based on the operational Integrated Forecast System (IFS) (version Cy31r2) operationally used at ECMWF between 2006 and 2007. Note that above the tropopause, no direct humidity observation is assimilated and all supersaturation is suppressed, which means that, in the stratosphere, the humidity distribution is mainly controlled by troposphere-to-stratosphere exchange, advec- 
tion and methane oxidation schemes in IFS. Specifications of the forecast model, data assimilation system and assimilated data sets are thoroughly described by Dee et al. (2011).

Unlike the reanalyses, which are based on a single version of the data assimilation system and forecast model, the operational analyses have benefited from significant modifications of the IFS and the $12 \mathrm{~h}$ 4-D-Var data assimilation system over the period 2001-2011. The changes over this period which have had most impact on $\mathrm{H}_{2} \mathrm{O}$ fields are a revised convection scheme, introduced in 2007 (Cy32r3), the better account for ice supersaturation in 4-D-Var in 2009 (Cy35r3) and a new cloud scheme in 2010 (Cy36r4). The horizontal resolution of the analyses is also higher than that of the reanalyses, with T511 spectral resolution $(39 \mathrm{~km})$ and 61 vertical levels from 2001 to 2006, which increased to T1279 $(16 \mathrm{~km})$ and 91 levels in 2010. Note that, at the present time, ECMWF high-resolution model produces analyses thanks to a new cubic octahedral grid of Tco1279 horizontal resolution $(9 \mathrm{~km})$ and 137 vertical levels (Cy41r2). Documentation related to model changes is available online at the following address: http://www.ecmwf.int/en/forecasts/ documentation-and-support/changes-ecmwf-model.

Compared to FISH measurements, about $30 \%$ of the ERA-Interim reanalyses were found to be in very good agreement (deviation from the model $<10 \%$ ), both in very dry and very wet conditions, and another $57 \%$ have been defined to be in fairly good agreement with the model (deviation $<50 \%$ ). Only $13 \%$ of the data showed large positive or negative biases (deviation $>50 \%$ ). The authors also analysed the data as a function of their geographical repartition, i.e. in the tropics, in the subtropics and in the extratropics, using the height of the thermal tropopause as a proxy. In the LS, at all latitudes, the deviation of FISH observations from ERA-Interim is very small, which means that there is no lower stratospheric wet bias as suggested in studies of earlier ECMWF analysis or reanalysis fields (Oikonomou and O'Neil, 2006; Luo et al., 2007; Flentje et al., 2007; Schäfler et al., 2010). Only the extratropical tropopause region ( $\pm 4 \mathrm{~km}$ around the thermal tropopause) and tropical UT were shown to have deviations up to 10 times more than the observed values.

Focusing on the $\mathrm{H}_{2} \mathrm{O}$ amount and transport from UT to LS, Jiang et al. (2015) show that the reanalyses from ECMWF and from NASA Modern-Era Retrospective Analysis for Research and Applications (MERRA) and its newest release (MERRA2) overestimate annual global mean UT $\mathrm{H}_{2} \mathrm{O}$ by up to $\sim 150 \%$ compared to Microwave Limb Sounder (MLS) observations. Substantial differences in $\mathrm{H}_{2} \mathrm{O}$ transport that impact on $\mathrm{H}_{2} \mathrm{O}$ budget are also found between the observations and reanalyses. $\mathrm{H}_{2} \mathrm{O}$ transport across the tropical tropopause in the reanalyses is faster by up to $\sim 86 \%$ compared to MLS observations. In the tropical LS, the mean vertical transport from ECMWF is $168 \%$ faster than the MLS estimate, while MERRA and MERRA2 have vertical transport velocities within $10 \%$ of MLS values.
The comparison of operational analyses with FISH measurements presents similar patterns. The overall good agreement is contrasted by wet biases in the extratropical tropopause regions and dry bias in the tropical UT of similar order to those found in the reanalyses. Nevertheless, the authors pointed out that those biases were reduced by up to a factor of 2 in the operational analyses towards the end of the period of study (2011) with respect to ERA-Interim. This highlights the impact of the improvements of both the IFS and the assimilation system. In summary, the consistent biases found both in ERA-Interim and operational analyses emphasise the difficulty of properly accounting for dynamical processes, especially deep tropical convection, in the assimilation system and model to accurately represent the water vapour distribution in the UTLS.

The present study is intended to address one of the most debated aspects of the TTL and the LS, the budget of water vapour $\left(\mathrm{H}_{2} \mathrm{O}\right)$, and aspires to be a baseline for further studies related to the "Multiscale water budget in the upper troposphere and lower stratosphere in the TROpics" (TRO-pico) project (www.univ-reims.fr/TRO-pico). One of the TROpico aims is to monitor $\mathrm{H}_{2} \mathrm{O}$ variations in the TTL and the LS linked to deep overshooting convection during field campaigns, which took place in the austral summer of 2012 and 2013 in Bauru, Sao Paulo state, Brazil, involving a combination of balloon-borne, ground-based and space-borne observations and modelling. TRO-pico's objectives are to evaluate to what extent the overshooting convection and processes involved contribute to the stratospheric water vapour entry. Small- and medium-sized balloons were launched as part of two field campaigns (2012 and 2013) held during the convective period in Bauru, Sao Paulo state, Brazil. Flights carrying Pico-SDLA (Tunable Laser Diode Spectrometer; Durry et al., 2008) and Flash-B (Yushkov et al., 1998) hygrometers were launched early morning and late evening, while radiosondes were launched up to four times a day during the most convective period. The measurements, still under analysis, are matched with space-borne and model data.

To evaluate the local results obtained in Bauru with respect to a larger scale, comparisons with climatologies were necessary. Although seasonal and annual variations of $\mathrm{H}_{2} \mathrm{O}$ have been extensively studied, few studies were devoted to the geographical and temporal variability of its diurnal cycle in the TTL. In Carminati et al. (2014), the impact of the continental tropical convection on the $\mathrm{H}_{2} \mathrm{O}$ variability was debated by considering the 8-year Microwave Limb Sounder (MLS) $\mathrm{H}_{2} \mathrm{O}$, cloud ice water content and temperature data sets from 2005 to 2014. The interplays between these parameters and their role in the water vapour variability in the TTL were highlighted separately in the northern and southern tropics. The analysis from Carminati et al. (2014) adopted the Liu and Zipser (2009) philosophy to discuss the difference between daytime and night-time data sets, with the aim of better apprehending the role of continental convection in hydrating and dehydrating processes in the TTL. 
According to Carminati et al. (2014), in the tropical upper troposphere $(177 \mathrm{hPa})$, continents, including the maritime continent, present the nighttime (01:30 local time, LT) peak in the water vapour mixing ratio characteristic of the $\mathrm{H}_{2} \mathrm{O}$ diurnal cycle above tropical land. The western Pacific region, governed by the tropical oceanic diurnal cycle, has a daytime maximum (13:30 LT). In the TTL (100 hPa) and tropical lower stratosphere $(56 \mathrm{hPa})$, South America and Africa differ from the maritime continent and western Pacific, displaying a daytime maximum of $\mathrm{H}_{2} \mathrm{O}$. The MLS water vapour and cloud ice water observations demonstrated a clear contribution to the TTL moistening by ice crystals overshooting over tropical land regions. The process was found to be much more effective in the southern tropics. Deep convection is responsible for the diurnal temperature variability in the same geographical areas in the lowermost stratosphere, which in turn drives the variability of $\mathrm{H}_{2} \mathrm{O}$.

Following results obtained by Carminati et al. (2014), we have used the opportunity of constraining chemical transport model (CTM) $\mathrm{H}_{2} \mathrm{O}$ outputs with MLS $\mathrm{H}_{2} \mathrm{O}$ measurements by using the assimilation techniques. The present paper intends to assess the quality of the assimilated $\mathrm{H}_{2} \mathrm{O}$ fields to study troposphere to stratosphere transport in the tropics focusing on the $\mathrm{H}_{2} \mathrm{O}$ budget. A companion paper will mainly deal with the scientific implications of the assimilated fields to trace the diurnal evolution of $\mathrm{H}_{2} \mathrm{O}$ in the TTL (Carminati et al., 2016) with a temporal resolution of $1 \mathrm{~h}$.

Meteorological analyses from ARPEGE developed at Météo-France are more dehydrated in the UTLS region than the space-borne observations of the Aura Microwave Limb Sounder (MLS) instrument by 1 to 2 ppmv (Payra et al., 2014). Within the TRO-Pico project, the primary motivation of this study is to understand the dynamical and chemical processes affecting the $\mathrm{H}_{2} \mathrm{O}$ budget in the tropical UTLS for the essential role in climate change through a CTM. The main issue is to critically diagnose and improve the CTM using the assimilation technique.

The present paper is structured as follows. Section 2 describes the observational data, while Sect. 3 presents the MOCAGE-VALENTINA assimilation system and Sect. 4 the description of the experiments. The assimilated fields are analysed in Sect. 5 and validated in Sect. 6. A sensitivity study is developed in Sect. 7, and finally Sect. 8 concludes the analysis.

\section{Observations}

\subsection{Aura/MLS water vapour observations}

The MLS instrument on board the NASA's Earth Observing System (EOS) Aura satellite (Waters et al., 2006) provides global measurements of temperature, ice cloud and 16 chemical species including water vapour from the upper troposphere to the mesosphere (Read et al., 2007; Lambert et al., 2007). The instrument measures $\sim 3500$ vertical profiles per day in five spectral regions $(118,190,240,640$ and $2500 \mathrm{GHz}$ ) along a sun-synchronous sub-orbital track with equatorial crossings at 01:30 and 13:30 local time (LT). $\mathrm{H}_{2} \mathrm{O}$ is retrieved from the $183 \mathrm{GHz} \mathrm{H_{2 }} \mathrm{O}$ rotational line spectrum within the 316 to $0.002 \mathrm{hPa}$ pressure range. The present study was conducted using MLS $\mathrm{H}_{2} \mathrm{O}$ Level 2 Version 3.3 (hereafter referred to as V3; Livesey et al., 2011) from August 2011 to March 2012. A sensitivity study has been performed in Sect. 7 comparing the analyses with $\mathrm{MLS} \mathrm{H}_{2} \mathrm{O}$ V3 and MLS $\mathrm{H}_{2} \mathrm{O}$ Level 2 Version 4.2 (hereafter referred to as V4; Livesey et al., 2015).

The $\mathrm{H}_{2} \mathrm{O}$ profiles in $\mathrm{V} 3$ (V4) are characterised by a vertical resolution varying from 2 to $3.5 \mathrm{~km}(1.3-3.5 \mathrm{~km})$ in the $316-1 \mathrm{hPa}$ pressure range, and a precision greater than $20 \%$ (greater than $20 \%$ ) for pressure greater than $147 \mathrm{hPa}, 20$ $10 \%(20-7 \%)$ between 121 and $83 \mathrm{hPa}$ and less than $8 \%$ (less than $6 \%$ ) between 68 and $1 \mathrm{hPa}$. The accuracy is greater than $15 \%$ for pressure greater than $147 \mathrm{hPa}, 12-7 \%$ between 121 and $83 \mathrm{hPa}$ and less than $9 \%$ between 68 and $1 \mathrm{hPa}$ for both versions (Livesey et al., 2011, 2015).

Hurst et al. (2014) reported agreement better than $1 \%$ between the National Oceanic and Atmospheric Administration (NOAA) frost point hygrometer and MLS V3 from 68 to $26 \mathrm{hPa}$ over three tropical sites. At 83 and $100 \mathrm{hPa}$, statistically significant biases from 0.1 to $0.3 \mathrm{ppmv}$ (from 3 to $8 \%$ ) were found, with MLS showing larger water vapour concentrations than the frost point hygrometer. Upper tropospheric pressure levels of 121 and $147 \mathrm{hPa}$ were recently investigated in Hurst et al. (2015) in the tropics, showing significant biases of 0.5 and 3.0 ppmv, respectively. MLS mean biases for MLS V4 are slightly smaller at 83,100 and $121 \mathrm{hPa}$ than for $\mathrm{V} 3(<0.2 \mathrm{ppmv})$, but are larger at $147 \mathrm{hPa}(\sim 0.5 \mathrm{ppmv})$.

With a methodology approaching that of Carminati et al. (2014), we will consider, in the following, the three independent vertical layers in the TTL, for which the most representative averaging kernels peak at $121 \mathrm{hPa}$ for the upper troposphere (UT), $100 \mathrm{hPa}$ for the tropopause (TP) and $68 \mathrm{hPa}$ for the lower stratosphere (LS). See for instance Fig. 3 of Carminati et al. (2014) for a representation of the three vertical layers. Figure 1 shows the monthly averaged $\mathrm{MLS}_{2} \mathrm{O}$ V3 fields in the UT, TP and LS in January 2012. We clearly observe the three different tropical regimes depending on the layer considered. Maxima of $\mathrm{H}_{2} \mathrm{O}$ are detected above the intense convective areas in the UT: western Pacific, Africa and South America, and a minimum over the Maritime Continent. Minima of $\mathrm{H}_{2} \mathrm{O}$ are detected when reaching the cold point tropopause in the TP: western Pacific, Maritime Continent, Africa and, to a lesser extent, South America. In addition, a zonally symmetric field of $\mathrm{H}_{2} \mathrm{O}$ is measured in the LS with no imprint of convective activity from the UT or TP whatever the area considered.

The number of measurements per $5^{\circ} \times 5^{\circ}$ bin at $100 \mathrm{hPa}$ is shown Fig. 2 for MLS V3 $\mathrm{H}_{2} \mathrm{O}$ fields in January 2012. We note that, in general, the tropical domain (30-50 measure- 
(a)

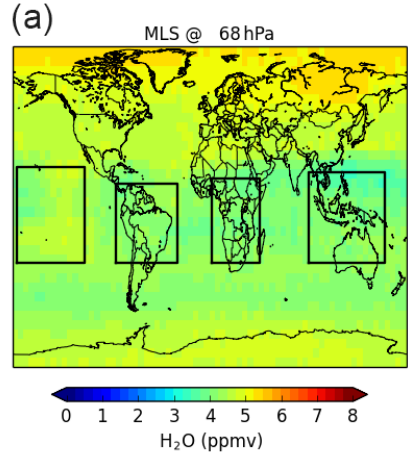

(b)

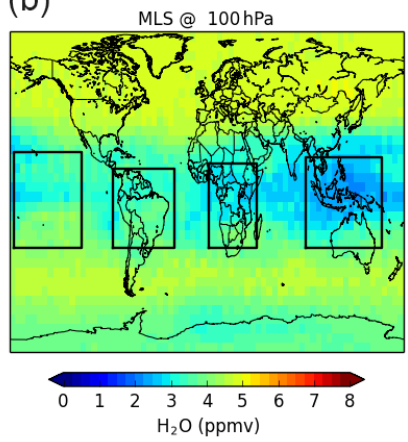

(c)

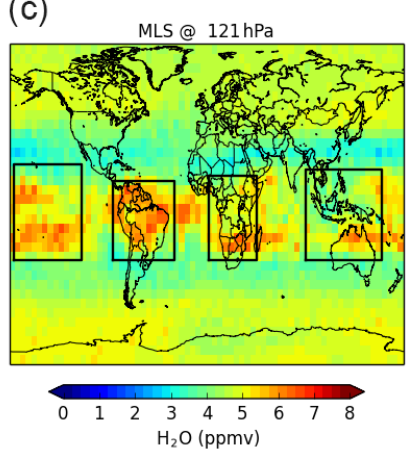

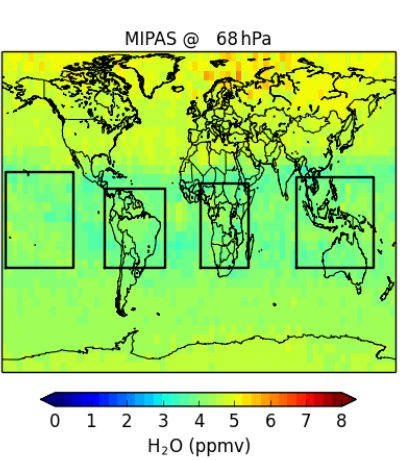
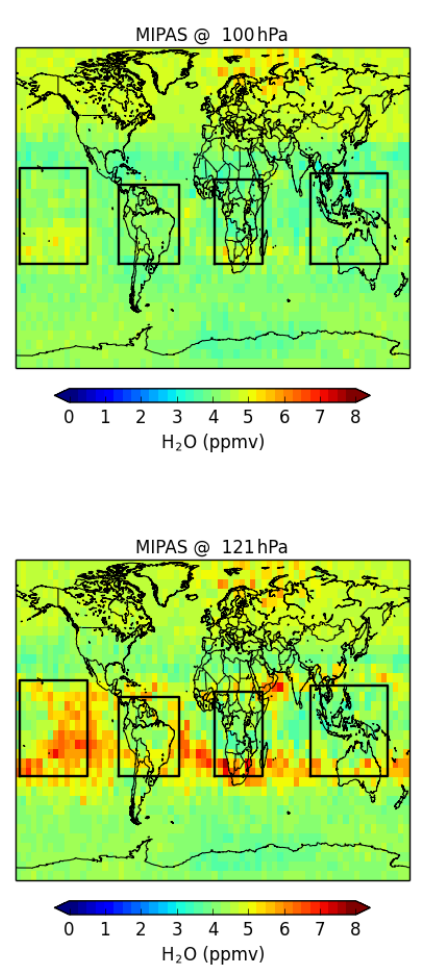

Figure 1. (a) Monthly averaged $\mathrm{H}_{2} \mathrm{O}$ fields at $68 \mathrm{hPa}$ in January 2012 in the MLS (left) and MIPAS (right) observation space (in space and time coincidence with MLS and MIPAS observations, respectively). (b) Same as the upper panel but at $100 \mathrm{hPa}$. (c) Same as the upper panel but at $121 \mathrm{hPa}$.

ments per bin) contains fewer measurements than the highlatitude domain (40-60 measurements per bin) because of the sun-synchronous orbit of the AURA satellite. We also note that, in the tropics above South America, Africa and the Maritime Continent, the number of measurements per bin is less than 30 because of the presence of clouds that impacts both the rejection of cloud-contaminated spectra and the quality of the retrievals.

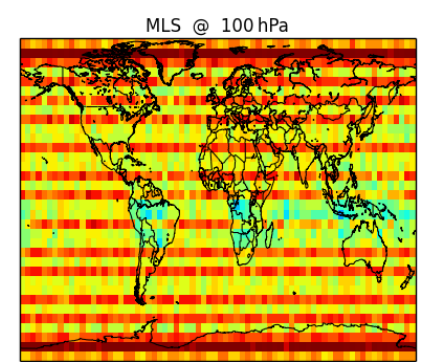

(a)

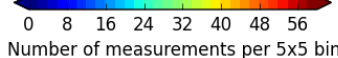

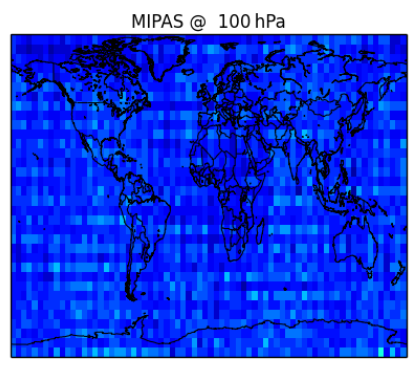

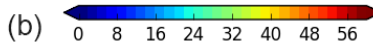
Number of measurements per $5 \times 5$ bin
Figure 2. Number of measurements averaged within $5^{\circ} \times 5^{\circ}$ bins at $100 \mathrm{hPa}$ in January 2012 in the MLS (left) and MIPAS (right) data sets.

\subsection{MIPAS}

The limb-viewing Fourier transform spectrometer named Michelson Interferometer for Passive Atmospheric Sounding (MIPAS) (Fischer et al., 2008) is on board the ESA satellite Envisat. It has been designed to operate in the midinfrared spectral region covering five spectral bands between 685 and $2410 \mathrm{~cm}^{-1}$ with an unapodised full spectral resolution of $0.025 \mathrm{~cm}^{-1}$. The instrument was launched into a sun-synchronous orbit by ESA on 1 March 2002. It passes the Equator in a southwards direction 14.3 times each day at 10:00 LT. The Envisat mission, and consequently the MIPAS instrument, ended on 8 April 2012.

MIPAS operated predominantly in its nominal measurement mode from July 2002 until the end of March 2004 Then, due to an instrument failure, it operated with reduced spectral resolution $\left(0.0625 \mathrm{~cm}^{-1}\right)$ for the benefit of an equivalent improvement in spatial sampling. The duty cycle of this so-called optimised resolution mode has been steadily increasing from $30 \%$ in January 2005 to $100 \%$ from December 2007 (Wetzel et al., 2013). MIPAS measures at 19 tangent points; tangent altitudes are latitude-dependent from 7 to $50 \mathrm{~km}$ over the poles and 13 to $56 \mathrm{~km}$ over the equator. A latitude-dependent floating altitude-sampling grid is used in order to roughly follow the tropopause height along the orbit with the requirement of collecting at least one spectrum within the troposphere but avoiding too many cloud-affected spectra (Chauhan et al., 2009). The instantaneous vertical field of view covers $3 \mathrm{~km}$; i.e. oversampling is achieved in the troposphere and lower stratosphere. Due to its emission sounding capability, MIPAS records spectra of the atmosphere during the day and night (Stiller et al., 2012). Retrieval of temperature and trace gases from the optimisedresolution nominal observation mode at the Institute of Meteorology and Climate Research (IMK) at the Karlsruhe Institute of Technology in cooperation with the Instituto de Astrofisica de Andalucia (IAA) is described in von Clarmann et al. (2009). The retrieval is based on constrained inverse modelling of limb radiances. 
We present the results of a validation study of water vapour, version V5R_H2O_221, retrieved with the IMK/IAA (Institut für Meteorologie und Klimaforschung, Karlsruhe/Instituto de Astrofisica de Andalucia, Grenada) MIPAS scientific level 2 processor. Only valid profiles have gone into the analysis by considering a filter visibility equal to 1 . The retrieval version is based on ESA level 1 spectra from version IPF 5. The MIPAS version V5R_H2O_221 $\mathrm{H}_{2} \mathrm{O}$ water vapour has a vertical resolution of $2.3 \mathrm{~km}$ at $20 \mathrm{~km}$ and $6.9 \mathrm{~km}$ at $50 \mathrm{~km}$, and the horizontal resolution is $206 \mathrm{~km}$ at $20 \mathrm{~km}$ and $436 \mathrm{~km}$ at $40 \mathrm{~km}$. Single profile precisions are $0.2 \mathrm{ppmv}$ at $10 \mathrm{~km}$ and $0.92 \mathrm{ppmv}$ at $50 \mathrm{~km}$ (Tschanz et al., 2013).

Figure 1 shows the monthly averaged MIPAS $\mathrm{H}_{2} \mathrm{O}$ fields in the UT, TP and LS in January 2012. In the UT, MLS V3 and MIPAS $\mathrm{H}_{2} \mathrm{O}$ fields are consistent over the tropics with maxima over the eastern Pacific Ocean, South Africa, and South Indian Ocean, and minima over the Maritime Continent, whilst two great differences occur above the western Pacific and South America, with maxima in the MLS field and minima in the MIPAS field. In the TP, the Maritime Continent and Africa are strongly dehydrated $(\sim 2 \mathrm{ppmv})$ in the MLS V3 field, whilst the MIPAS $\mathrm{H}_{2} \mathrm{O}$ field does not show any longitudinal gradient ( $\sim 4 \mathrm{ppmv})$. Above, in the LS, MIPAS and MLS V3 $\mathrm{H}_{2} \mathrm{O}$ fields are very consistent with each other showing a zonally symmetric field of $\sim 4$ ppmv.

The number of measurements per $5^{\circ} \times 5^{\circ}$ bin at $100 \mathrm{hPa}$ is shown Fig. 2 for MIPAS $\mathrm{H}_{2} \mathrm{O}$ fields in January 2012. About 10-15 measurements per bin can be retrieved within the whole month, with no great differences above the continents except maybe above Africa $(<10)$. Nevertheless, the MIPAS sampling ( $\sim 8-15$ per bin) is, on average, much less than the MLS V3 sampling ( 30-60 per bin) in January 2012 (Fig. 2) and also whatever the month considered from September 2011 to March 2012 (not shown).

\section{The MOCAGE-VALENTINA assimilation system}

In this study, the global atmospheric composition is simulated using MOCAGE (Modèle de Chimie Atmosphérique à Grande Echelle). It is a three-dimensional CTM developed at Météo-France (Peuch et al., 1999), which covers the planetary boundary layer, the free troposphere and the stratosphere. It provides a number of optional configurations with varying domain geometries and resolutions, as well as chemical and physical parameterisation packages. It has the flexibility to use several chemical schemes for stratospheric (e.g. El Amraoui et al., 2008) and tropospheric studies (e.g. Ricaud et al., 2014), and has been validated using a large number of measurements during the Intercontinental Transport of Ozone and Precursors (ICARTT/ITOP) campaign (Bousserez et al., 2007).

MOCAGE uses a semi-Lagrangian transport scheme and includes 47 sigma-hybrid vertical levels from the surface

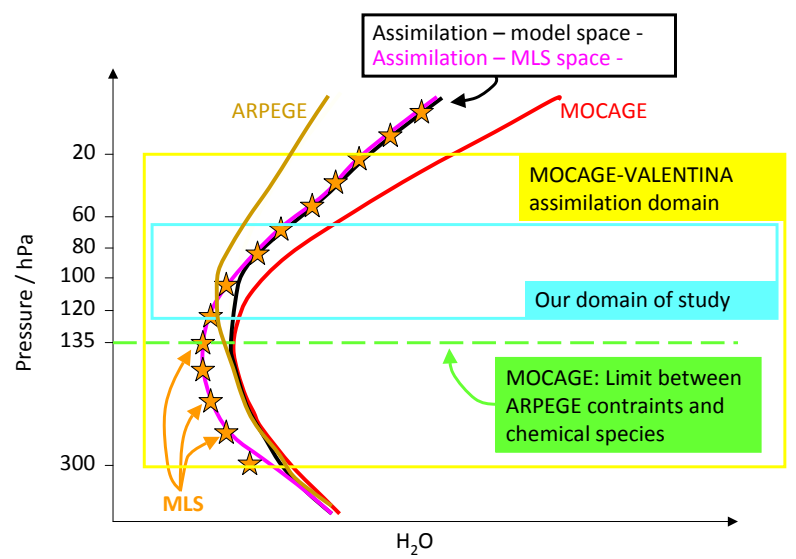

Figure 3. Schematic representation of the $\mathrm{H}_{2} \mathrm{O}$ vertical profiles used in the present analysis: MLS (orange stars), MOCAGE (red line), ARPEGE (brown line), assimilation in the MLS space (in time and space coincidence with MLS observations, pink line) and assimilation in the model space (in time and space coincidence with the model outputs, black line). In MOCAGE, $\mathrm{H}_{2} \mathrm{O}$ is constrained to ARPEGE meteorological analyses below $135 \mathrm{hPa}$ (horizontal dashed green line), and is considered as a chemical species above $135 \mathrm{hPa}$. MLS observations are assimilated from 300 to $20 \mathrm{hPa}$. Our domain of study lies from 121 to $68 \mathrm{hPa}$ in the tropics.

up to $5 \mathrm{hPa}$. It has a vertical resolution of about $800 \mathrm{~m}$ in the vicinity of the tropopause and in the lower stratosphere. For our study, we have used a global model configuration with an horizontal resolution of $2^{\circ}$ both in latitude and longitude, driven dynamically every $3 \mathrm{~h}$ by wind, temperature, pressure, surface pressure and specific humidity fields issued from ARPEGE analyses (Courtier et al., 1991). The condensation scheme is based on the probability density function from Smith (1990). Supersaturation is not allowed by the physics but can be created by horizontal advection and then removed by the physics. Surface anthropogenic emission is prescribed using the Monitoring Atmospheric Composition and Climate (MACC) emission database, and fire events are accounted for by using the Global Fire Emissions Database (GFED) version 3 inventory (Randerson et al., 2013).

To sum up, the microphysical, the dynamical and the radiative schemes are all treated by ARPEGE. MOCAGE only considers the chemical scheme. Consequently, water vapour in MOCAGE is treated as a chemical species when its value is less than $10 \mathrm{ppmv}$ (roughly near $150 \mathrm{hPa}$ ); otherwise it is treated as a meteorological parameter from ARPEGE. However, to achieve the goal of our study, namely to constrain MOCAGE $\mathrm{H}_{2} \mathrm{O}$ as chemical species by actually using MLS observations at 121, 100 and $83 \mathrm{hPa}$, we have modified this initial treatment by considering a transition level at $135 \mathrm{hPa}$. Tests have shown that $135 \mathrm{hPa}$ was the optimum transition level since, for transition pressures greater than $135 \mathrm{hPa}$, the impact of ARPEGE $\mathrm{H}_{2} \mathrm{O}$ on the assimilated fields in the upper troposphere/tropopause layer was negligible. In conclu- 
sion, (i) for pressures greater than $135 \mathrm{hPa}, \mathrm{H}_{2} \mathrm{O}$ is calculated directly from ARPEGE specific humidity, and (ii) for pressures less than $135 \mathrm{hPa}$, the $\mathrm{H}_{2} \mathrm{O}$ distribution is fully controlled by MOCAGE via the chemistry and transport schemes. This has the main advantage of being very simple to run but has the main drawback of producing unrestricted supersaturation in the upper troposphere/tropopause layer (see Sect. 5.2). Figure 3 gives a schematic representation of the $\mathrm{H}_{2} \mathrm{O}$ vertical profiles used in the current study. It depicts the separating limit between ARPEGE constraints and MOCAGE chemical species.

The assimilation system, used here to incorporate MLS $\mathrm{H}_{2} \mathrm{O}$ observations in MOCAGE, is the VALENTINA system, which was initially developed in the framework of the ASSET (ASSimilation of Envisat daTa) project (Lahoz et al., 2007), and has been used in numerous atmospheric chemistry data assimilation studies (Massart et al., 2009; El Amraoui et al., 2010). It is developed jointly by Météo-France and CERFACS (Centre Européen de Recherche et de Formation Avancée en Calcul Scientifique). Herein, we used a 3D-FGAT formulation (3-D-Variational in the First Guess at Appropriate Time variant; Fisher and Andersson, 2001). For variational systems, the assimilation method is based on the minimisation of the cost function, $J$, that can be formulated using the notation of Ide et al. (1997):

$$
\begin{aligned}
& J(x)=J_{\mathrm{b}}+J_{\mathrm{o}} \\
& J_{\mathrm{b}}=\frac{1}{2}\left[x\left(t_{0}\right)-x^{\mathrm{b}}\left(t_{0}\right)\right]^{T} \mathbf{B}^{-1}\left[x\left(t_{0}\right)-x^{\mathrm{b}}\left(t_{0}\right)\right] \\
& J_{\mathrm{o}}=\frac{1}{2} \sum_{i=0}^{N}\left[y^{\mathrm{o}}\left(t_{i}\right)-H_{i}\left(x\left(t_{i}\right)\right)\right]^{T} \mathbf{R}_{i}^{-1}\left[y^{\mathrm{o}}\left(t_{i}\right)-H_{i}\left(x\left(t_{i}\right)\right)\right] .
\end{aligned}
$$

$J_{\mathrm{b}}$ is the misfit to the background state and $J_{\mathrm{o}}$ represents the misfit to the observations. $x^{\mathrm{b}}\left(t_{0}\right)$ and $y^{\mathrm{o}}\left(t_{i}\right)$ are the background state at the initial time $t_{0}$ and the observation at time $t_{i}$, respectively. $\mathbf{B}$ and $\mathbf{R}$ are the background and the observation error covariance matrices, respectively. $x\left(t_{i}\right)$ is the model state at the observation time, $t_{i}$, and represents the propagation of the initial state, $x\left(t_{0}\right)$, by the model operator, $M$ :

$x\left(t_{i}\right)=M_{i} x\left(t_{0}\right)$.

$H_{i}$ is the observation operator, generally non-linear, which maps the model state $x\left(t_{i}\right)$ to the measurement space where $y^{\mathrm{o}}\left(t_{i}\right)$ is located. The subscript $i$ refers to time, and $N$ is the number of time steps in the assimilation window $\left[t_{0}, t_{N}\right]$.

Since we are interested in the study of the diurnal cycle of $\mathrm{H}_{2} \mathrm{O}$ in the tropical tropopause based on the work from Carminati et al. (2014), we have set up VALENTINA with an assimilation window of $1 \mathrm{~h}$ to assimilate MLS $\mathrm{H}_{2} \mathrm{O}$ observations. Although the VALENTINA system has the capability of including the effect of the averaging kernel, which takes into account vertical variations of the sensitivity of the retrieval to the actual $\mathrm{H}_{2} \mathrm{O}$ mixing ratios, we will not use this opportunity in the present study (see Sect. 4). In VALENTINA, the background error covariance matrix (B) formulation is based on the diffusion equation approach (Weaver and Courtier, 2001) and can be fully specified by means of a 3-D standard deviation field (diagonal of $\mathbf{B}$ ) and 3-D fields of horizontal $\left(L_{x}\right.$ and $\left.L_{y}\right)$ and vertical $\left(L_{z}\right)$ local correlation lengths. This assimilation technique has already produced good-quality results compared to independent data sets, especially for $\mathrm{O}_{3}$ and $\mathrm{CO}$ (see e.g. Abida et al., 2016; El Amraoui et al., 2010; Claeyman et al., 2011).

\section{Description of the experiments}

It is worth pointing out that $\mathrm{H}_{2} \mathrm{O}$ as a chemical species in MOCAGE (135-5 hPa pressure range) suffers from a strong systematic bias in the UTLS region, especially in the tropics. Hence, in order to reduce the magnitude of this bias, we performed a relatively long assimilation run of 6-month duration using MLS V3 (and also MLS V4) observations from 1 August 2011 to 31 January 2012.

The most crucial ingredient in a variational assimilation procedure is the background error covariance matrix, $\mathbf{B}$, which spreads out information extracted from observations in the vertical and horizontal directions in space and weights the importance of the a priori state. For this study, we used a simple parameterisation for the $\mathbf{B}$ matrix, consistently with the analysis presented in El Amraoui et al. (2014). The horizontal correlation lengths $\left(L_{x}\right.$ and $\left.L_{y}\right)$ are taken to be homogeneous and equal to about $200 \mathrm{~km}$. The vertical correlation length $L_{z}$ is set to one vertical model grid point. Similarly to Emili et al. (2014), the background standard deviation 3$\mathrm{D}$ field (model error) is parameterised as a vertically varying percentage of the background profile. Roughly, it is set to $45 \%$ up to $135 \mathrm{hPa}, 35 \%$ in $135-50 \mathrm{hPa}$ and to $15 \%$ in 50 $5 \mathrm{hPa}$.

The long-run experiment was initialised on 1 August 2011 at 00:00 UTC from a climatological state. In the assimilation process, only MLS $\mathrm{H}_{2} \mathrm{O}$ measurements, which are in the 316-5 hPa pressure range, are used (Fig. 3). Although the MOCAGE-VALENTINA system is able to take into account the averaging kernels, we have not used the $\mathrm{MLS}_{2} \mathrm{O}$ averaging kernels in our study because we found unrealistic values in some regions of the globe. Our system associates one averaging kernel to one measurement. However, in the case of MLS observations, only seasonally and zonally averaged averaging kernels are provided and this might produce instabilities. Hence, only $\mathrm{H}_{2} \mathrm{O}$ measurements and their associated errors are incorporated in our 3-D-FGAT assimilation process. Note that the MLS observations will only constrain the model in the $135-5 \mathrm{hPa}$ pressure range where $\mathrm{H}_{2} \mathrm{O}$ is freely evolving as a chemical species. In contrast, in the 316-135 $\mathrm{hPa}$ pressure range, the information extracted from the observations is completely lost each time the MOCAGE $\mathrm{H}_{2} \mathrm{O}$ field is updated by the ARPEGE constraint (Fig. 3). 


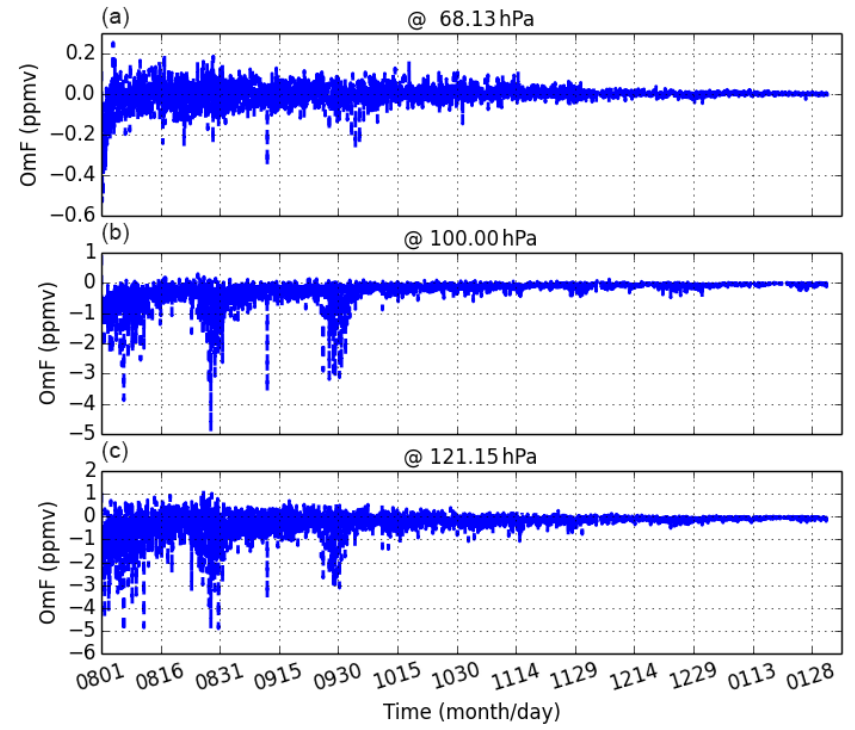

Figure 4. Observations minus forecasts zonally averaged over the tropics $\left(30^{\circ} \mathrm{S}-30^{\circ} \mathrm{N}\right)$ from 1 August 2011 to 31 January 2012 at $121 \mathrm{hPa}(\mathbf{c}), 100 \mathrm{hPa}(\mathbf{b})$ and $68 \mathrm{hPa}(\mathbf{a})$.

Figure 4 shows the temporal evolution of observations minus forecasts $(\mathrm{OmF})$ during the long-run (1 August 2011-31 January 2012) assimilation experiment at three MLS pressure levels: 121, 100 and $68 \mathrm{hPa}$. The MLS-assimilated observations minus their forecast-equivalent values are averaged over the tropics $\left(30^{\circ} \mathrm{S}-30^{\circ} \mathrm{N}\right)$ for each hour. The time evolution of the zonally averaged $\mathrm{OmF}$ at the three levels is a key indicator of the potential gain of the assimilation tools. Indeed, the 3-D-FGAT assimilation does not just act as a clever filter or interpolation of observations, it also improves the background knowledge as observations are injected into the system as time evolves. This is clearly indicated in Fig. 4.

In August 2011, the background state is, by definition, set to the free model. The model forecast is initially high biased with respect to MLS observations at $121 \mathrm{hPa}$ (about $-4 \mathrm{ppmv}$ ) and at $100 \mathrm{hPa}$ (about $-2 \mathrm{ppmv}$ ), whilst it is unbiased at $68 \mathrm{hPa}$ with a variability of $\pm 0.1 \mathrm{ppmv}$ (Fig. 4). The OmF magnitude decreases gradually with time over the whole long-run experiment time period. It takes about 4 months of assimilation, by December 2011, to reach a model forecast state with minimum values of $\mathrm{OmF}$ reduced to $\pm 0.2 \mathrm{ppmv}$ at $121 \mathrm{hPa}, \pm 0.1 \mathrm{ppmv}$ at $100 \mathrm{hPa}$ and $\pm 0.05 \mathrm{ppmv}$ at $68 \mathrm{hPa}$. This means that, by December 2011, the background state is no longer set to the free model but rather close to the observations. This emphasises the extreme difficulty of constraining the MOCAGE $\mathrm{H}_{2} \mathrm{O}$ field, which is marked by important biases, when assimilating only MLS measurements.

On 1 December 2011 at 00:00 UTC, we perform a free model simulation (without assimilating MLS observations) that is initialised by the obtained analysis state. The $\mathrm{H}_{2} \mathrm{O}$

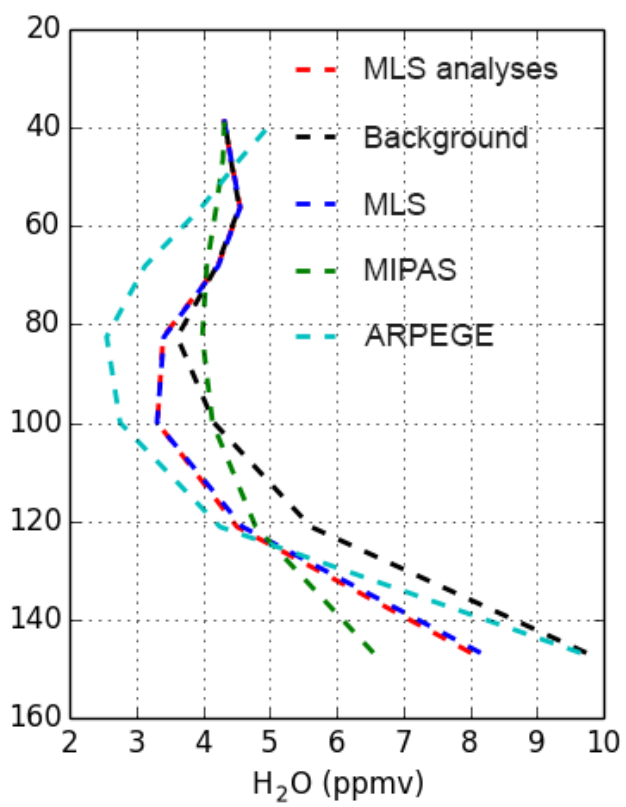

Figure 5. Monthly averaged vertical profiles of $\mathrm{H}_{2} \mathrm{O}$ in the tropical UTLS $\left(30^{\circ} \mathrm{S}-30^{\circ} \mathrm{N}\right)$ in January 2012 in the MLS observation space from MLS analyses (red dashed line), background (black dashed line), MLS (blue dashed line), MIPAS (green dashed line) and ARPEGE (light blue line).

field analyses will be compared with those from the free run in order to quantify the corrections brought by the MLS measurements in the model.

\section{The assimilated fields}

The analyses are produced from 1 November 2011 to 31 March 2013; however, the study concentrates on monthly averaged $\mathrm{H}_{2} \mathrm{O}$ fields in January and February 2012. Because we used different data sets calculated or measured at different times and locations not necessarily consistent within all the data sets, the analyses will be presented within three spaces in time and space coincidences with MLS (hereafter referred to as the MLS space) and MIPAS (the MIPAS space) observations and with the model outputs (the model space).

\subsection{Vertical profiles in the tropics}

In order to highlight the quality of the different data sets used in our study around the tropical tropopause, Fig. 5 shows the vertical profiles of zonally averaged $\mathrm{H}_{2} \mathrm{O}$ in January 2012 over the tropical UTLS $\left(30^{\circ} \mathrm{N}-30^{\circ} \mathrm{S}\right)$ in the MLS observation space from background, MLS, MIPAS, ARPEGE and the assimilated field (MLS analyses). First of all, it is noted that the vertical distribution of the MLS analyses is consistent with the MLS data. The background field is wetter than the MLS analyses in the UT $(\sim 1.5 \mathrm{ppmv}$ at $150 \mathrm{hPa}$ ), and is consistent with the MLS analyses in the 

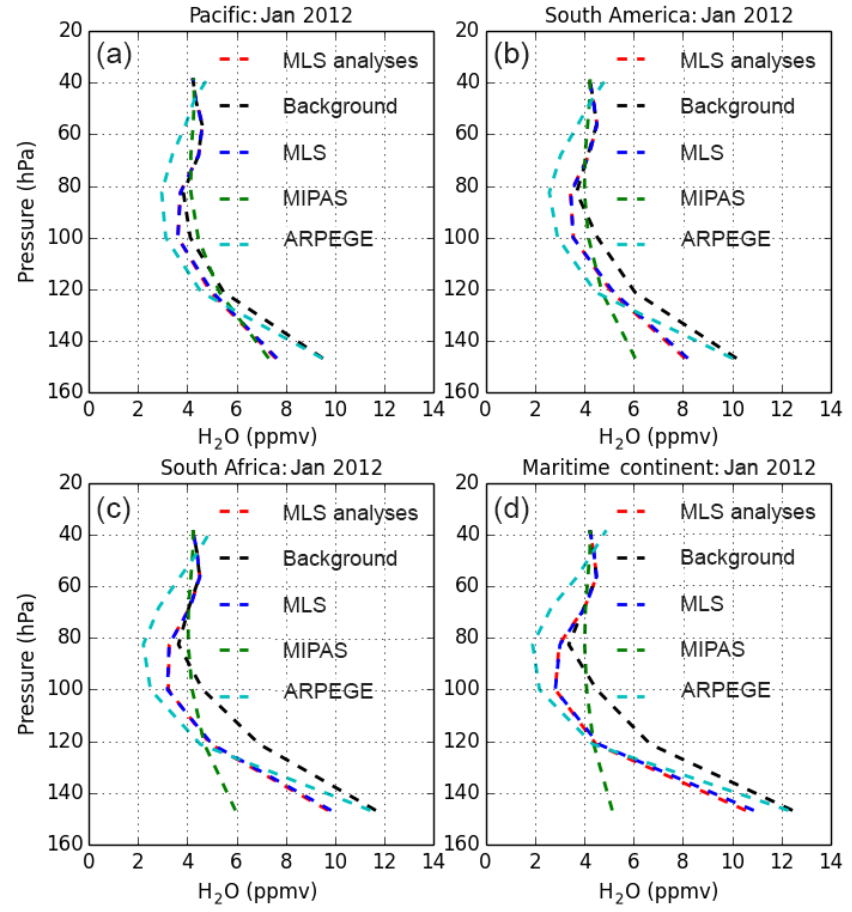

Figure 6. Monthly averaged vertical profiles of $\mathrm{H}_{2} \mathrm{O}$ in January 2012 in the MLS observation space from MLS analyses (red dashed line), background (black dashed line), MLS (blue dashed line), MIPAS (green dashed line) and ARPEGE (light blue line) in four different tropical areas (see Fig. 1): Pacific Ocean (a), South America (b), South Africa (c) and the Maritime Continent (d).

LS above $80 \mathrm{hPa}$. The ARPEGE field, although wetter in the $\mathrm{UT}(\sim 1.5 \mathrm{ppmv}$ at $150 \mathrm{hPa})$, is drier than the MLS analyses around the tropopause from 120 to $50 \mathrm{hPa}$ with a minimum of $\sim 2.5 \mathrm{ppmv}$ at $80 \mathrm{hPa}$. Finally, it is noted that the MIPAS field is drier by $1.5 \mathrm{ppmv}$ than the MLS analyses below $130 \mathrm{hPa}$, wetter by $1 \mathrm{ppmv}$ from 130 to $70 \mathrm{hPa}$ and drier by $0.5 \mathrm{ppmv}$ from 70 to $40 \mathrm{hPa}$.

Because of the great longitudinal variability of $\mathrm{H}_{2} \mathrm{O}$ in the tropics, we have separated all the data into four main boxes, namely eastern Pacific $\left(30^{\circ} \mathrm{S}-21^{\circ} \mathrm{N}, 176-114^{\circ} \mathrm{W}\right)$, South America $\left(30^{\circ} \mathrm{S}-12^{\circ} \mathrm{N}, 86-30^{\circ} \mathrm{W}\right)$, southern Africa $\left(30^{\circ} \mathrm{S}-\right.$ $\left.12^{\circ} \mathrm{N}, 2-46^{\circ} \mathrm{E}\right)$ and the Maritime Continent $\left(30^{\circ} \mathrm{S}-18^{\circ} \mathrm{N}\right.$, $90-160^{\circ} \mathrm{E}$ ). Figure 6 shows the same fields as in Fig. 5 but separated into the four above-mentioned areas. The five data sets show the same general features, namely a wet UT, a dry LS and a hygropause (minimum of $\mathrm{H}_{2} \mathrm{O}$ ) around the tropopause whatever the box considered. Although all the data sets are consistent in the LS $(40-60 \mathrm{hPa})$, some differences are worthwhile discussing. Among all the four domains, the Maritime Continent shows, on average, the wettest UT (10.5-12.5 ppmv at $140 \mathrm{hPa}$ for all the data sets except MIPAS) and the driest hygropause (less than 2 ppmv for ARPEGE) because the tropopause is the coldest over this domain compared to all the other domains. In the UT, MIPAS
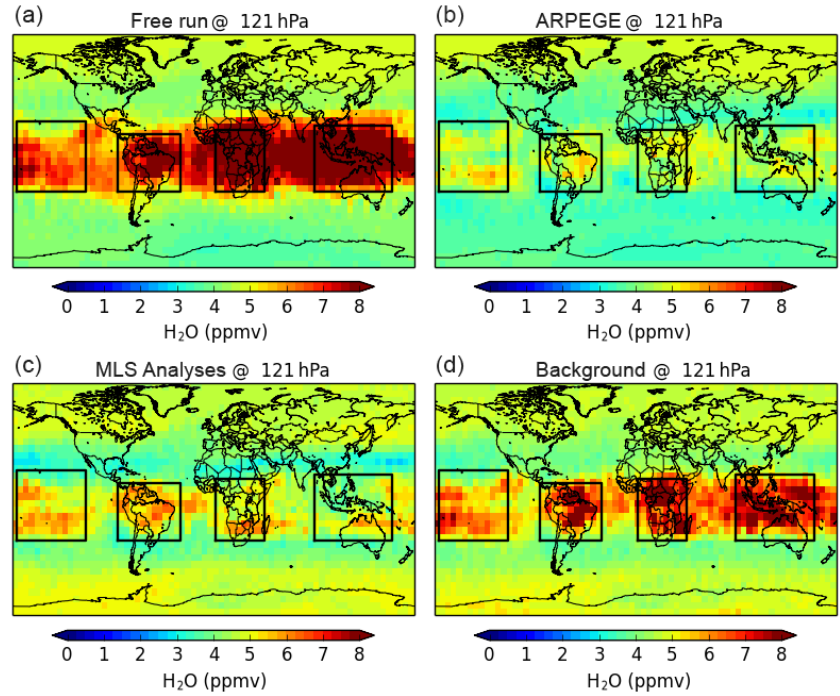

Figure 7. Monthly averaged $\mathrm{H}_{2} \mathrm{O}$ fields at $121 \mathrm{hPa}$ in January 2012 in the MLS observation space (in time and space coincidence with MLS observations) from the free run (MOCAGE, a), ARPEGE (b), MLS analyses (assimilation, c) and the background (d).

data are, on average, much drier than all the other data sets by 4-7 ppmv, except over the eastern Pacific. The fact that MIPAS behaves very differently compared to all the other data sets above the Maritime Continent might be a consequence of the systematic presence of clouds over this area. Since cloudcontaminated spectra are discarded in the MIPAS analysis, a sampling bias towards a drier atmosphere might be generated. Around the tropopause, the hygropause is located either at $100 \mathrm{hPa}$ (MLS and MLS analyses) or $80 \mathrm{hPa}$ (ARPEGE, MIPAS, background). A local maximum is systematically detected around $60 \mathrm{hPa}$ over the four geographical domains in the MLS, MLS analyses and background data sets, although it is absent in the MIPAS and ARPEGE data sets.

\subsection{Global distribution in the MLS space}

The data sets are now studied at global scale along three different pressure levels: $121 \mathrm{hPa}$ (UT), $100 \mathrm{hPa}$ (TP) and $68 \mathrm{hPa}$ (LS). In this study, we will mainly analyse the tropical band $\left(30^{\circ} \mathrm{S}-30^{\circ} \mathrm{N}\right)$. The monthly averaged $\mathrm{H}_{2} \mathrm{O}$ fields representative of January 2012 in the MLS space (namely in time and space coincidence with the MLS observations) from the free run (MOCAGE), ARPEGE, MLS analyses and the background are displayed in Figs. 7-9 at 121, 100 and $68 \mathrm{hPa}$, respectively.

At $121 \mathrm{hPa}$ (Fig. 7), all the data sets show local maxima above the South American and the African continents, the central Pacific, and the Maritime Continent, namely where convective systems are the most intense and the most efficient to bring high humidity from the lowermost to the uppermost troposphere. Both the free run and the background data sets are highly hydrated with maxima around or greater 

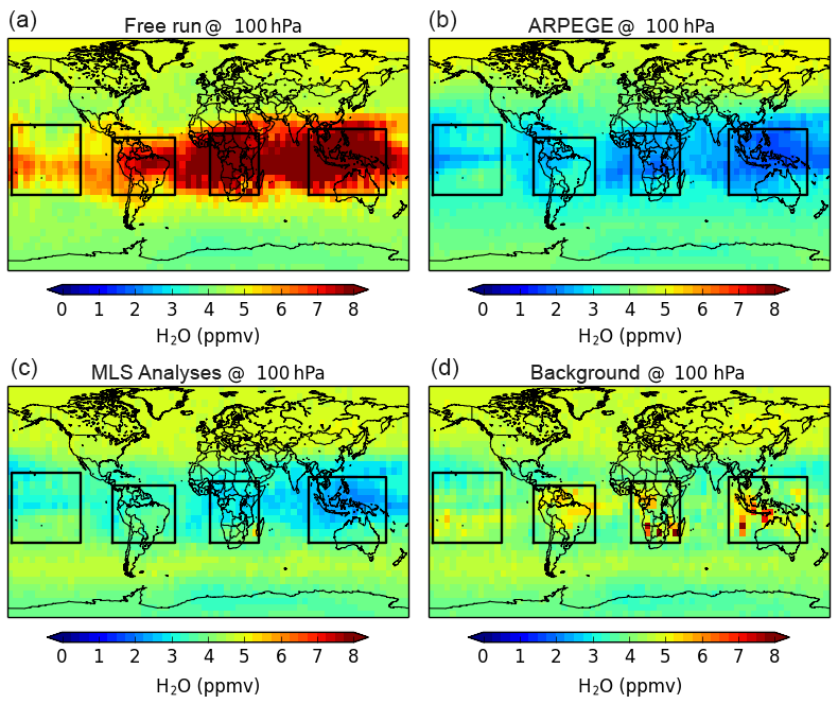

Figure 8. Monthly averaged $\mathrm{H}_{2} \mathrm{O}$ fields at $100 \mathrm{hPa}$ in January 2012 in the MLS observation space (in time and space coincidence with MLS observations) from the free run (MOCAGE, a), ARPEGE (b), MLS analyses (assimilation, c) and the background (d).

than 8 ppmv, whilst the MLS analyses and the ARPEGE data sets show maxima of about 5-6 ppmv. ARPEGE should represent the reference in the UT. Although all the other data sets are wetter than ARPEGE, the analyses are drier than the background by about $1 \mathrm{ppmv}$ consistently with the MLS data field (Fig. 1), underlining the positive impact of the assimilation technique to constrain the background by the observations.

At $100 \mathrm{hPa}$ (Fig. 8), the four $\mathrm{H}_{2} \mathrm{O}$ fields tend to show different behaviours. ARPEGE and the analyses exhibit a dehydrated tropopause $(<3 \mathrm{ppmv})$, whilst the background shows some local maxima above the continents (5-6 ppmv) and the free run a highly hydrated tropopause with values much greater than 8 ppmv above the continents and the Indian Ocean. The free run, namely MOCAGE, cannot reproduce the dehydrated tropopause since it does not contain any microphysical processes to transform supersaturated air into ice particles over convective continental and ocean areas. The background field is not as hydrated as the free run as a consequence of the assimilation process but is nevertheless wetter than the "true" atmosphere as represented by ARPEGE. The assimilation technique efficiently constrains the background by the MLS observations to produce analyses much drier by 2-3 ppmv than the background fields, although slightly wetter than ARPEGE by about 1 ppmv but with consistent local minima above the South American, African and Maritime continents, as in MLS (Fig. 1).

At $68 \mathrm{hPa}$ (Fig. 9), the free run and ARPEGE data sets strongly differ from each other but also differ from MLS analyses and background with a wet atmosphere in the free run (5-8 ppmv), a dry atmosphere in ARPEGE (1-4 ppmv)
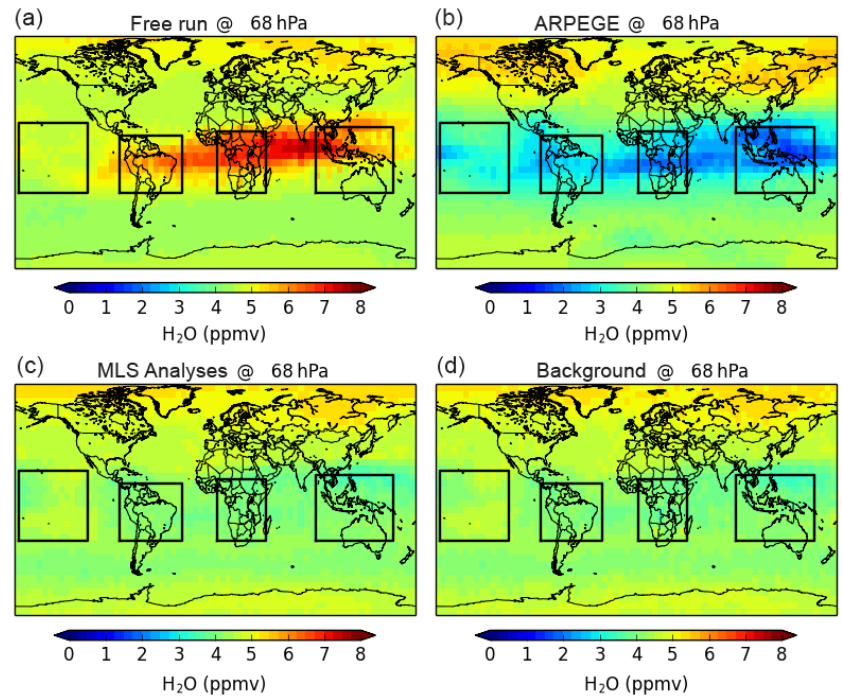

Figure 9. Monthly averaged $\mathrm{H}_{2} \mathrm{O}$ fields at $68 \mathrm{hPa}$ in January 2012 in the MLS observation space (in time and space coincidence with MLS observations) from the free run (MOCAGE, a), ARPEGE (b), MLS analyses (assimilation, c) and the background (d).

and a moderately dry atmosphere in the analyses and background around 4 ppmv. The free run data set is too affected by the tropospheric injection of wet air masses and allows unrestricted supersaturation as explained at $100 \mathrm{hPa}$. ARPEGE tends to systematically show a dry lower stratosphere, probably because of the impact of a dry bias in the meteorological soundings above the tropopause. The background and the analyses are very consistent with each other and with MLS (see Fig. 1), underlining the fact that the assimilation technique has produced a $\mathrm{H}_{2} \mathrm{O}$ field very close to the MLS observations.

\subsection{Global distribution in the model space}

The monthly averaged $\mathrm{H}_{2} \mathrm{O}$ fields representative of January 2012 in the model space (namely in time and space coincidence with the MOCAGE and ARPEGE outputs) from the free run (MOCAGE), ARPEGE, MLS analyses and the background are displayed in Figs. 10-12 at 121, 100 and $68 \mathrm{hPa}$, respectively. At $121 \mathrm{hPa}$ (Fig. 10), a very wet atmosphere is calculated in the free run, the background and the analyses with local maxima above the South American, the African and the Maritime continents ( $>7 \mathrm{ppmv}$ ), although ARPEGE and MLS (Fig. 1) are much drier, with local maxima of 5 and 6 ppmv, respectively. Since the background and the analyses are almost identical in the model space contrary to what has been observed in the MLS space (see previous section), this means that the MLS observations are too sparse both in time and space to optimally constrain the background field. In other words, outside of the assimilation window and outside of the horizontal domain where MLS observations are taken, the assimilation system tends to converge to a back- 

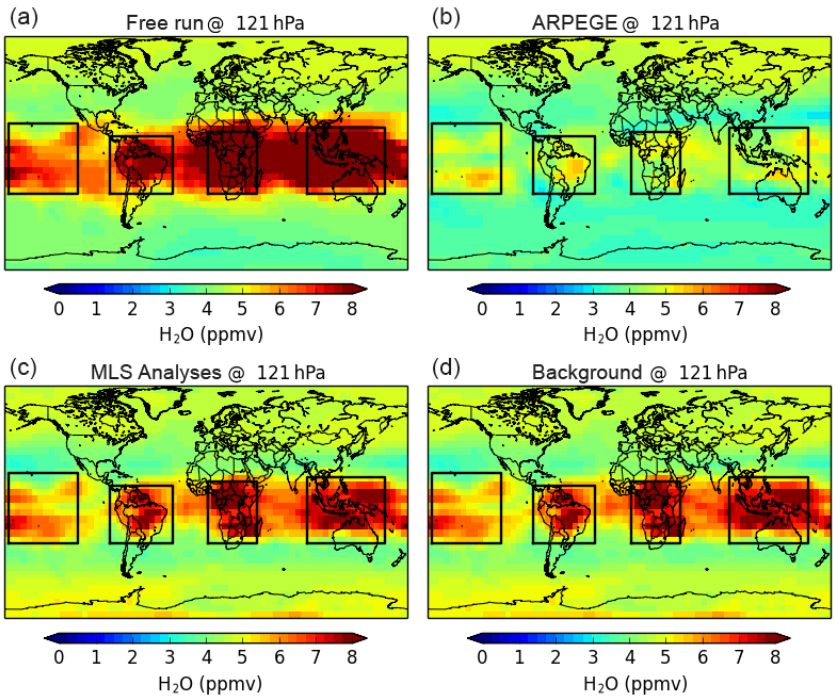

Figure 10. Monthly averaged $\mathrm{H}_{2} \mathrm{O}$ fields at $121 \mathrm{hPa}$ in January 2012 in the model space (in the model grid and time samplings) from the free run (MOCAGE, a), ARPEGE (b), MLS analyses (assimilation, c) and the background (d).
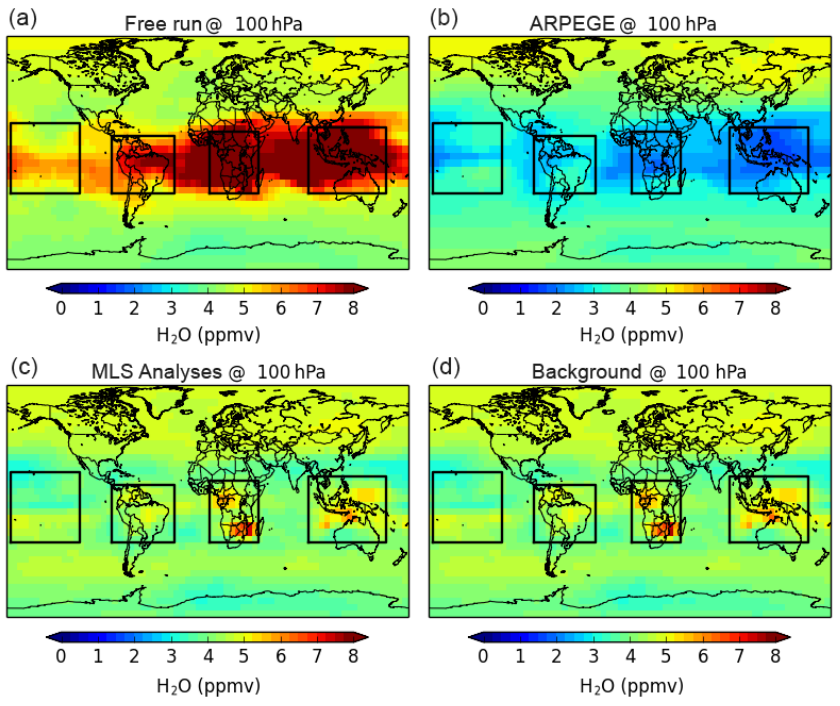

Figure 11. Monthly averaged $\mathrm{H}_{2} \mathrm{O}$ fields at $100 \mathrm{hPa}$ in January 2012 in the model space (in the model grid and time samplings) from the free run (MOCAGE, a), ARPEGE (b), MLS analyses (assimilation, c) and the background (d).

ground state strongly influenced by the free run that is too wet.

At $100 \mathrm{hPa}$ (Fig. 11), the impact of the free run on the background is less important since the tropical tropopause of the background and of the analyses (4-6 ppmv) is much less hydrated than the free run tropopause $(>8 \mathrm{ppmv})$ but is still wetter than both ARPEGE and MLS observations
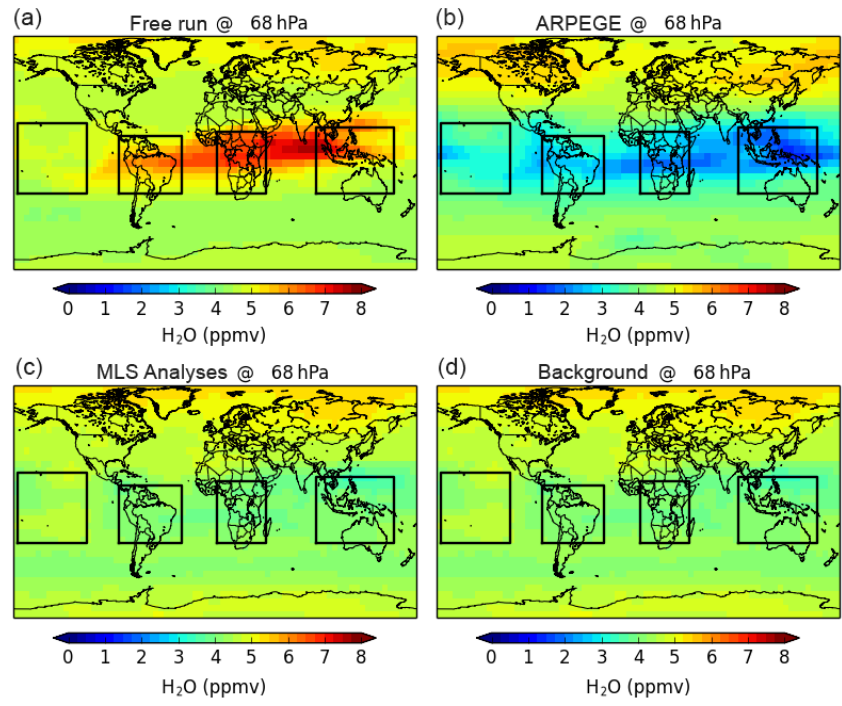

Figure 12. Monthly averaged $\mathrm{H}_{2} \mathrm{O}$ fields at $68 \mathrm{hPa}$ in January 2012 in the model space (in the model grid and time samplings) from the free run (MOCAGE, a), ARPEGE (b), MLS analyses (assimilation, c) and the background (d).

$(<3 \mathrm{ppmv})$. As at $121 \mathrm{hPa}$, the background and the analyses are almost identical in the model space.

At $68 \mathrm{hPa}$ (Fig. 12), the background and the MLS analyses $(\sim 4$ ppmv) are very consistent with the MLS observations (Fig. 1), whilst ARPEGE is much drier $(<2$ ppmv) and the free run is much wetter ( $>6 \mathrm{ppmv}$ ). The assimilation system behaves nominally in the lower stratosphere since the background is no longer affected by the free run even outside of the assimilation window when and where the MLS observations are taken into account.

\section{Validation of the assimilated fields}

In order to validate the analyses, we have considered both the MIPAS data sets and the assimilated fields in the MIPAS space (namely in time and space coincidence with the MIPAS observations). The monthly averaged $\mathrm{H}_{2} \mathrm{O}$ fields representative of January 2012 in the MIPAS space from the free run (MOCAGE), ARPEGE, MLS analyses and the background are displayed in Figs. 13-15 at 121, 100 and $68 \mathrm{hPa}$, respectively. At $121 \mathrm{hPa}$ (Fig. 13), as in the model space, the analyses show a very wet upper troposphere ( $>8 \mathrm{ppmv}$ ) above the continents consistent with the background and the free run, but in contrast to ARPEGE (local maxima of $6 \mathrm{ppmv}$ ) and MIPAS observations (Fig. 1, maxima of $\sim 7$ ppmv). It nevertheless seems that the MIPAS observations above convective areas (South American, African and the Maritime continents) are dry-biased compared to MLS observations (as already discussed in Sect. 2.2). This is probably due to the impact of the cloud presence in the line of sight diminishing the number of available observations (see Fig. 2). Indeed, MLS mi- 

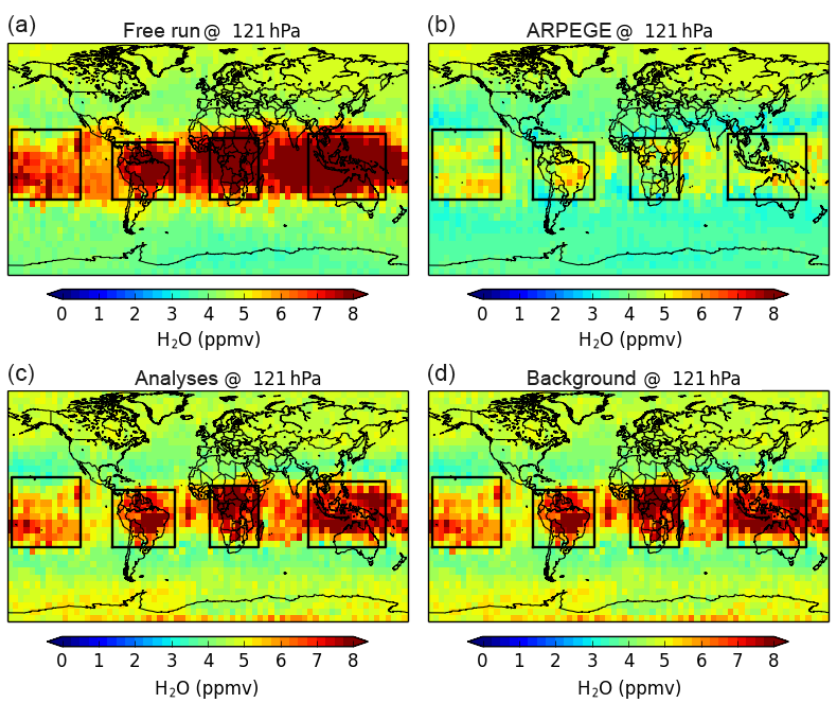

Figure 13. Monthly averaged $\mathrm{H}_{2} \mathrm{O}$ fields at $121 \mathrm{hPa}$ in January 2012 in the MIPAS observation space (in time and space coincidence with MIPAS observations) from the free run (MOCAGE, a), ARPEGE (b), MLS analyses (assimilation, c) and the background $(\mathbf{d})$.

crowave observations are, in general, less affected by clouds than the MIPAS infrared observations, consequently the MIPAS $\mathrm{H}_{2} \mathrm{O}$ field is given in a cloud-free atmosphere. The MLS and MIPAS measurements occur at two different local times (01:40/13:40 for MLS and 10:00/22:00 for MIPAS). Because of the diurnal cycle of the convective activity (Liu and Zipser, 2009) that differs above the ocean (maximum in local morning) and continents (maximum in local afternoon), the MIPAS observations are probably more affected by upper tropospheric clouds than the MLS observations, both over the continent and the ocean. Chauhan et al. (2009) and Montoux et al. (2009) tried to clarify this cloud issue by different approaches but could not clearly identify a consistent picture except the strong effects of clouds within the presented comparison. They also suggested that the observed $\mathrm{H}_{2} \mathrm{O}$ variability may be contaminated by the presence of clouds in the UTLS. Another issue is the altitude resolution of the MIPAS retrievals (Milz et al., 2005) in the lowermost layers at 121 and $100 \mathrm{hPa}$ that may be too coarse $(4.5-6.5 \mathrm{~km})$ to allow a direct comparison without the application of averaging kernels.

At $100 \mathrm{hPa}$ (Fig. 14), the analyses are very consistent with the MIPAS observations (Fig. 1, $\sim 4$ ppmv) except above the South American, the African and the Maritime continents where the analyses are wetter by 1-2 ppmv. The background and the analyses are identical and differ from the wet free run $(>8$ ppmv) and the dry ARPEGE $(<2$ ppmv) tropopause. The dehydration observed by MLS (Fig. 1) and by ARPEGE above the Maritime Continent is not reproduced by the analyses, probably because the free run is far too wet $(>8 \mathrm{ppmv})$
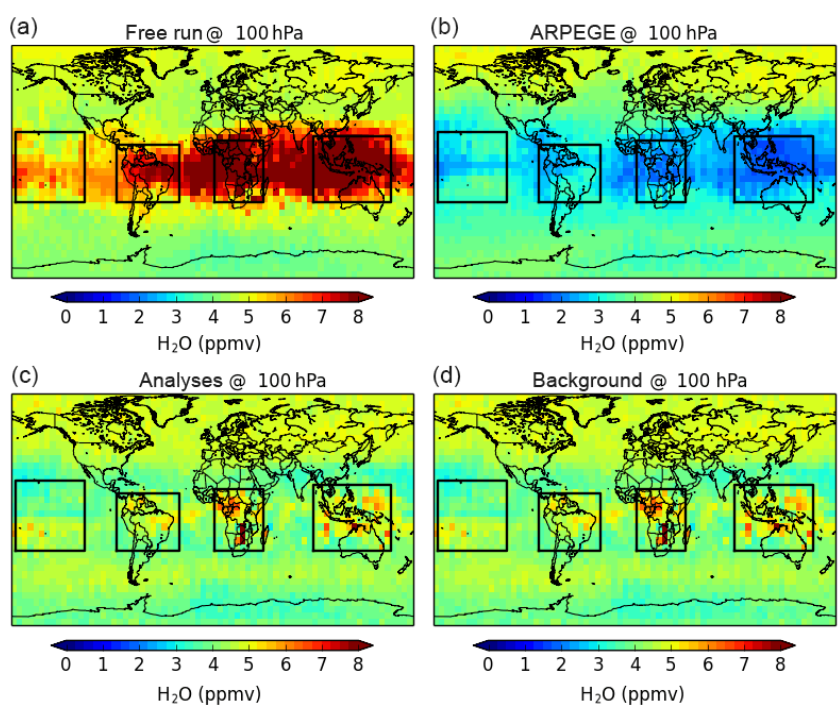

Figure 14. Monthly averaged $\mathrm{H}_{2} \mathrm{O}$ fields at $100 \mathrm{hPa}$ in January 2012 in the MIPAS observation space (in time and space coincidence with MIPAS observations) from the free run (MOCAGE, a), ARPEGE (b), MLS analyses (assimilation, c) and the background (d).
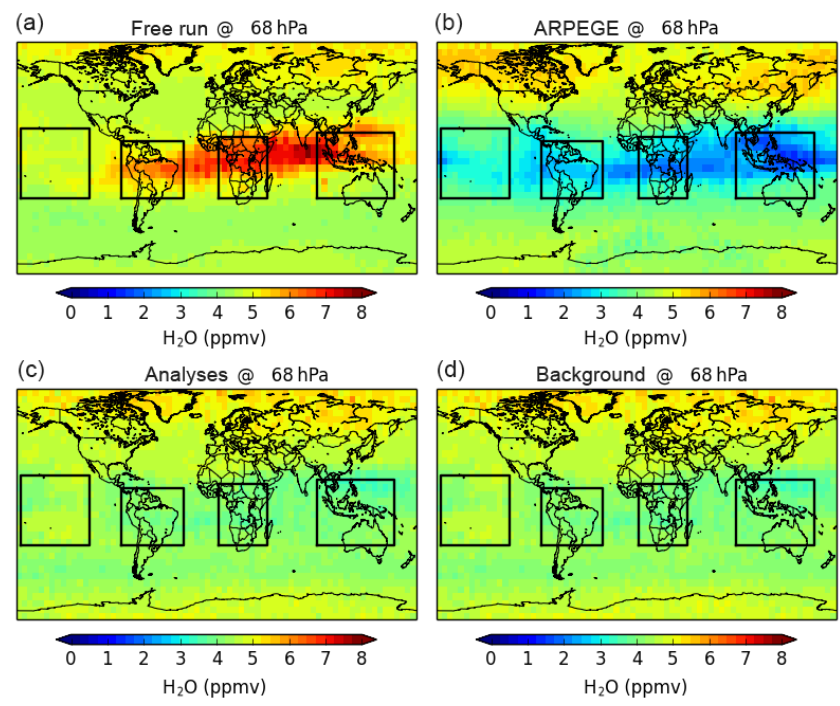

Figure 15. Monthly averaged $\mathrm{H}_{2} \mathrm{O}$ fields at $68 \mathrm{hPa}$ in January 2012 in the MIPAS observation space (in time and space coincidence with MIPAS observations) from the free run (MOCAGE, a), ARPEGE (b), MLS analyses (assimilation, c) and the background (d).

above this area and the assimilation system cannot cope with such a difference with the sparse MLS observations.

At $68 \mathrm{hPa}$ (Fig. 15), the analyses and the background are very consistent with the MIPAS observations $(\sim 4 \mathrm{ppmv})$ with no longitudinal gradient, although the free run and ARPEGE are wetter $(\sim 7 \mathrm{ppmv})$ and drier $(<2 \mathrm{ppmv})$, respectively. This tends to show that the assimilation system is 

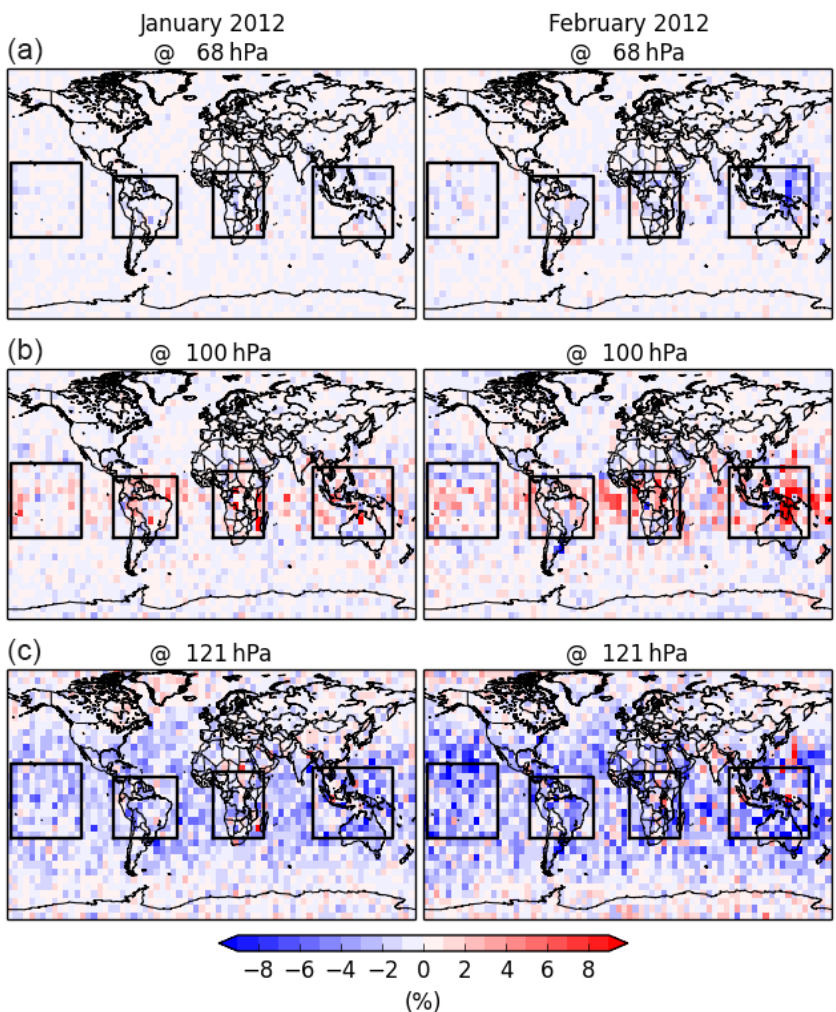

Figure 16. Relative difference between the $\mathrm{H}_{2} \mathrm{O}$ fields from the observation and the assimilation in January 2012 (left) and in February 2012 (right) at $121 \mathrm{hPa}(\mathbf{c}), 100 \mathrm{hPa}$ (b) and $68 \mathrm{hPa}(\mathbf{a})$.

working properly in the lower stratosphere, despite the fact that the MLS observations are sparse both in time and space.

To summarise, in the MLS space, the analyses behave consistently with the MLS observations from the upper troposphere to the lower stratosphere $(121-68 \mathrm{hPa})$. In the model space, the analyses are wetter than the "true" atmosphere as represented by ARPEGE and MLS in the upper troposphere $(121 \mathrm{hPa})$ and around the tropopause $(100 \mathrm{hPa})$, but are consistent with MLS and MIPAS in the lower stratosphere. In the MIPAS space, the sensitivity and the vertical resolution of the MIPAS data set at 121 and $100 \mathrm{hPa}$ prevent an assessment of the behaviour of the analyses, particularly over intense convective areas as the South American, the African and the Maritime continents; but, in the lower stratosphere $(68 \mathrm{hPa})$, the analyses are very consistent with MIPAS.

\section{Sensitivity studies}

We have used the opportunity of getting two versions of the MLS data to check the sensitivity of the assimilation technique to this parameter that affects both the quality of the data and the number of data available. However, beforehand, we investigated the impact of some periods with no measurements on the assimilated fields induced by the fact that, in
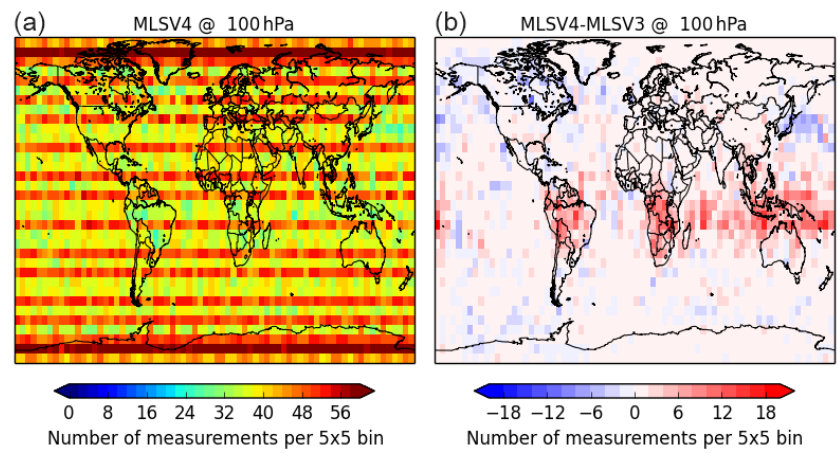

Figure 17. Number of measurements averaged within $5^{\circ} \times 5^{\circ}$ bins at $100 \mathrm{hPa}$ in January 2012 in the MLS V4 data set (a). Difference between the number of measurements averaged within $5^{\circ} \times 5^{\circ}$ bins at $100 \mathrm{hPa}$ in January 2012 in the MLS V4 and the MLS V3 data sets (b).

this configuration, the background returns back to the free run.

\subsection{Periods with no measurements}

We have already noticed that the $\mathrm{H}_{2} \mathrm{O}$ analyses in the tropical UTLS in the model and the MIPAS spaces were very sensitive to the background and consequently to the free run producing an atmosphere in the upper troposphere and in the tropopause wetter than in the MLS space. We investigate here the impact of periods of no MLS measurements on the $\mathrm{H}_{2} \mathrm{O}$ analyses during the assimilation time frame of 1 month. Two consecutive months are very interesting to consider. In January 2012, MLS operated nominally, and 31 days of measurements are available for the assimilation study. In contrast, in February 2012, 4 days of measurements were unavailable; thus the assimilation process used MLS data over the time frame 1-19 and 24-29 February.

The relative difference between the monthly averaged $\mathrm{H}_{2} \mathrm{O}$ fields from the observations and the assimilation in January and in February 2012 at 121, 100 and $68 \mathrm{hPa}$ is shown in Fig. 16. The impact of the missing data in February 2012 on the analyses compared to the January 2012 is clearly depicted. The observations minus analysis are, in absolute value, greater in February than in January: -6 vs. $-4 \%$ at $121 \mathrm{hPa},+4$ vs. $+2 \%$ at $100 \mathrm{hPa}$ and -2 vs. $+1 \%$ at $68 \mathrm{hPa}$ in February vs. January 2012, respectively. When the MLS data are no longer available, the background field tends to be redirected towards the free run, losing the memory of the MLS driving information injected into the assimilation system.

\subsection{Improvement of the data quality}

In this section, we investigated the impact of using two versions of the MLS data on the assimilation fields because the version affects both the quality of the data and the num- 

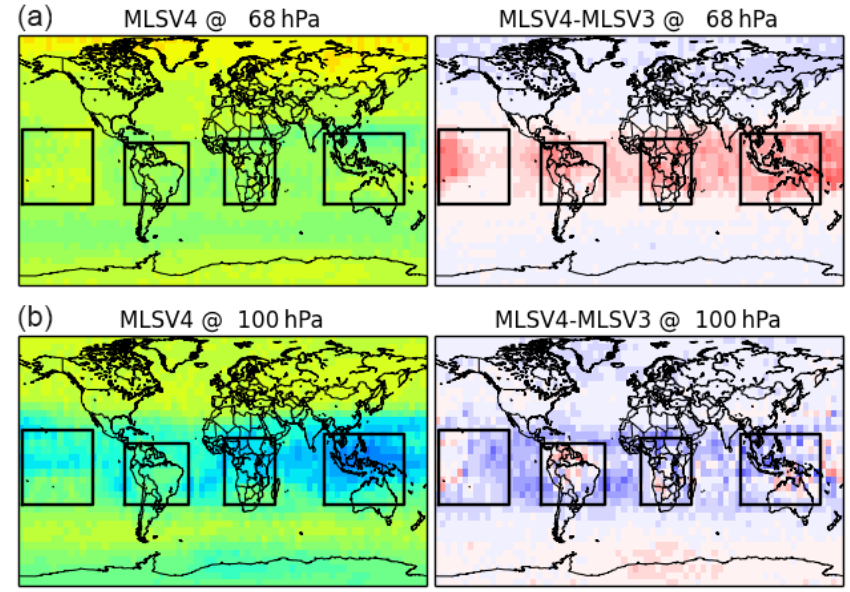

MLSV4-MLSV3 @ $100 \mathrm{hPa}$

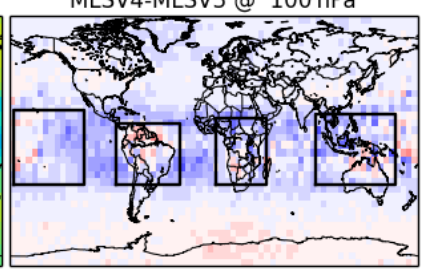

(c) MLSV4 @ $121 \mathrm{hPa}$
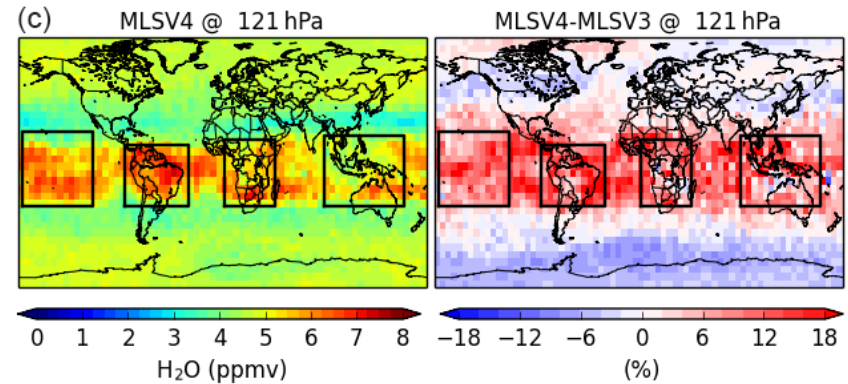

Figure 18. Monthly averaged $\mathrm{H}_{2} \mathrm{O}$ analyses in the MLS space in January 2012 using the MLS V4 data set (left) and relative difference between the MLS analyses using V4 and V3 data sets (right) at $121 \mathrm{hPa}(\mathbf{c}), 100 \mathrm{hPa}(\mathbf{b})$ and $68 \mathrm{hPa}(\mathbf{a})$.

ber of data available. The MLS V3 and V4 are presented in Sect. 2.1. Official documentation (Livesey et al., 2015) indicates an improvement in the cloud screening and first guess estimation from V3 to V4, which yielded better agreement with the truth in simulation studies. As an example, Fig. 17 shows the number of measurements per $5^{\circ} \times 5^{\circ}$ bin for January 2012, considering the MLS V4 data and the difference between the V4 and the V3 data. In the tropics, the number of measurements per bin in V4 is about 15 measurements per bin more than in V3, particularly over the South American, the African and the Maritime continents, and the Indian Ocean. This clearly shows a change, both in the cloud treatment and in the data quality of V4 compared to V3.

In a similar way as performed with the MLS V3, the assimilation process has thus been conducted with the MLS V4 data from 1 November 2011 to 31 March 2013, namely with a background error set to $45 \%$ up to $135 \mathrm{hPa}, 35 \%$ in $135-$ $50 \mathrm{hPa}$ and to $15 \%$ in $50-5 \mathrm{hPa}$ (see Sect. 4 for the other parameters). The monthly averaged analyses in January 2012 at 121,100 and $68 \mathrm{hPa}$ are presented in Figs. 18-20 in the MLS, model and MIPAS spaces, respectively together with the difference between the V4 and the V3 analyses. In the MLS space (Fig. 18), both versions show the same structures (maxima at $121 \mathrm{hPa}$ and minima at $100 \mathrm{hPa}$ over the con-
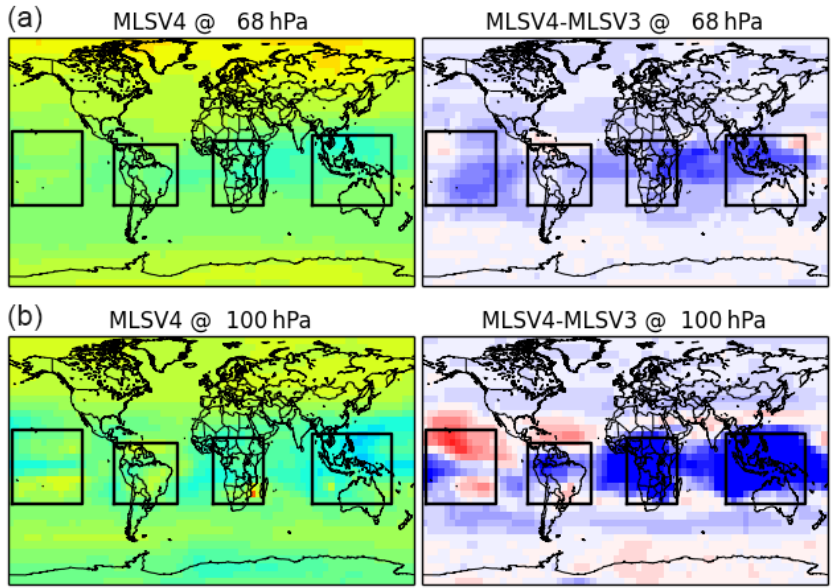

MLSV4-MLSV3 @ 100 hPa
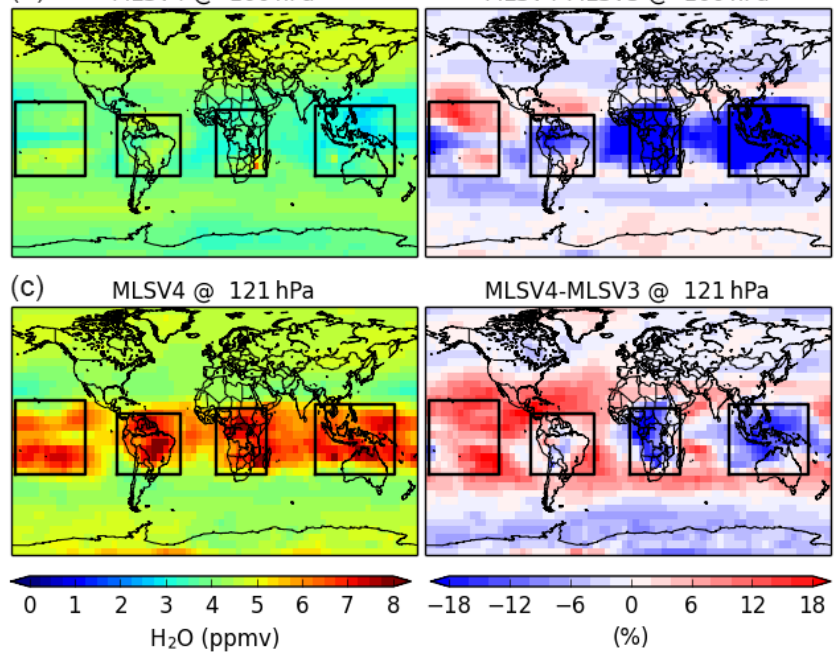

MLSV4-MLSV3 @ $121 \mathrm{hPa}$

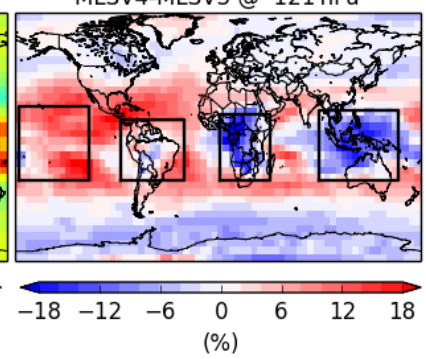

Figure 19. Monthly averaged $\mathrm{H}_{2} \mathrm{O}$ analyses in the model space in January 2012 using the MLS V4 data set (left) and relative difference between the MLS analyses using V4 and V3 data sets (right) at $121 \mathrm{hPa}(\mathbf{c}), 100 \mathrm{hPa}(\mathbf{b})$ and $68 \mathrm{hPa}(\mathbf{a})$.

vective areas) in the upper troposphere and the tropopause whilst a zonally symmetric field is detected in the tropical band in the lower stratosphere $(68 \mathrm{hPa})$. However, V4 analyses compared to V3 analyses tends to show a much wetter atmosphere in the tropical upper troposphere and lower stratosphere by 10 and $15 \%$, respectively and, at the tropopause, a slightly drier atmosphere by $2-3 \%$. Consequently, the difference in the analyses between the two versions in the tropics is only significant at 121 and $68 \mathrm{hPa}$, i.e. greater than the minimum measurable value of $0.1 \mathrm{ppmv}$ estimated in Livesey et al. $(2011,2015)$.

In the model space (Fig. 19), the two analyses behave differently depending on the level and the area considered. Above the convective areas such as South American, the African and the Maritime continents, the atmosphere is much drier in V4 compared to V3 by 10,20 and $5 \%$ at 121,100 and $68 \mathrm{hPa}$, respectively. Outside of these convective areas, the V4 compared to the V3 atmosphere is wetter by $10 \%$ at $121 \mathrm{hPa}$, and drier by about $5-10 \%$ at 100 and $68 \mathrm{hPa}$. This clearly shows the impact of V4 quality induced by cloudscreening methodology on the analyses over convective areas where the presence of clouds is prominent. Finally, in the MIPAS space (Fig. 20), the conclusions drawn for the model space are mainly the same: V4 analyses drier than V3 above 
(a) MLSV4 analyses @ 68 hPa MLSV4-MLSV3 analyses @ $68 \mathrm{hPa}$

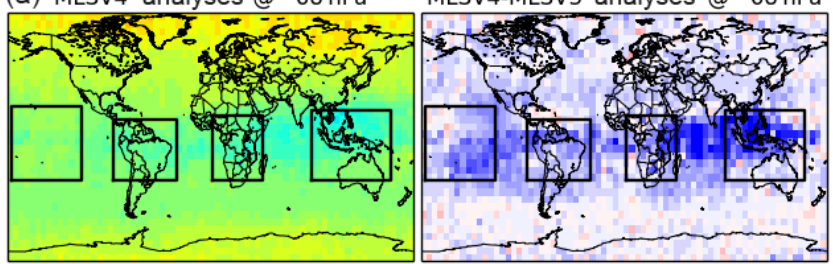

(b) MLSV4 analyses@100 hPa MLSV4-MLSV3 analyses @ $100 \mathrm{hPa}$

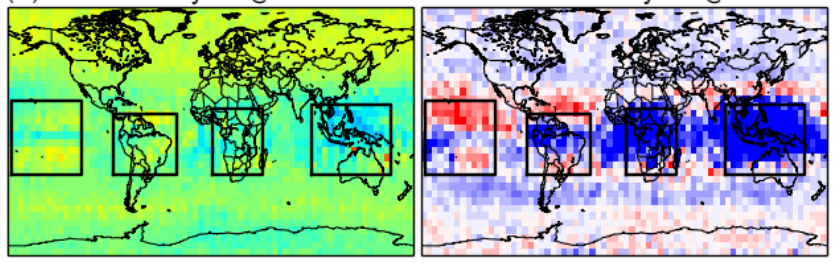

(c) MLSV4 analyses @ $121 \mathrm{hPa}$ MLSV4-MLSV3 analyses @ $121 \mathrm{hPa}$

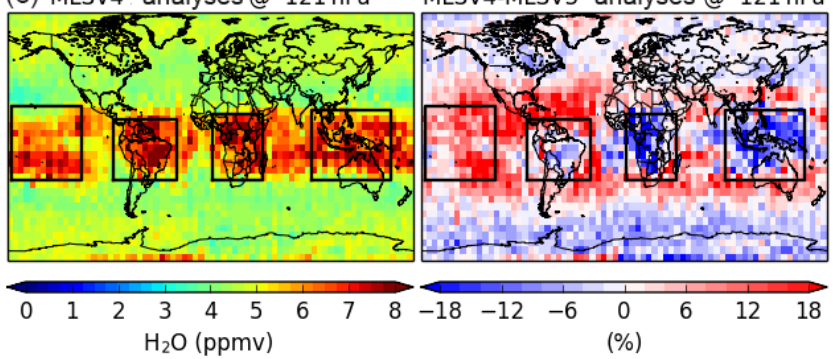

Figure 20. Monthly averaged $\mathrm{H}_{2} \mathrm{O}$ analyses in the MIPAS space in January 2012 using the MLS V4 data set (left) and relative difference between the MLS analyses using V4 and V3 data sets (right) at $121 \mathrm{hPa}(\mathbf{c}), 100 \mathrm{hPa}(\mathbf{b})$ and $68 \mathrm{hPa}(\mathbf{a})$.

the convective areas at the three levels considered and, outside of the convective areas, wetter $\mathrm{V} 4$ analyses at $121 \mathrm{hPa}$ and drier above.

\section{Conclusions}

Water vapour $\left(\mathrm{H}_{2} \mathrm{O}\right)$ in the tropical UTLS is known to play an important role in many aspects of meteorology, including radiation, dynamics, chemistry and climate change. Modelling of water in the UTLS is very challenging because it varies in space and time due to its rapid phase change (liquid, solid and gas). The representation of $\mathrm{H}_{2} \mathrm{O}$ in the tropical UTLS from observations and from models does not necessarily converge since some caveats are detectable that have an impact on the measured or calculated $\mathrm{H}_{2} \mathrm{O}$ fields, e.g. the presence of clouds in the observations and cloud microphysics in the model.

Within the French project, Multiscale water budget in the upper troposphere and lower stratosphere in the TROpics (TRO-pico), a global-scale analysis has been set up based on space-borne measurements, models and assimilation techniques to study the time evolution of $\mathrm{H}_{2} \mathrm{O}$ in the tropical UTLS. The MOCAGE-VALENTINA assimilation tool has been used to assimilate the Aura MLS version $3.3 \mathrm{H}_{2} \mathrm{O}$ mea- surements within the $316-5 \mathrm{hPa}$ range with an assimilation window of $1 \mathrm{~h}$. The time period spans from 1 August 2011 to 31 March 2013 but the study concentrates on monthly averaged $\mathrm{H}_{2} \mathrm{O}$ fields in January and February 2012. Some diagnostics based on observations minus analysis and forecast have been developed to assess the quality of the assimilated $\mathrm{H}_{2} \mathrm{O}$ fields. As a validation exercise, comparisons with two independent sources of $\mathrm{H}_{2} \mathrm{O}$ in the UTLS have been performed based on the space-borne MIPAS measurements and on the meteorological ARPEGE analyses. Sensitivity studies of the analysed fields have been done (1) considering periods when no MLS measurements are available and (2) using $\mathrm{H}_{2} \mathrm{O}$ data from another MLS version (4.2). The studies have been performed within three different spaces in time and space coincidences with the MLS (MLS space) and MIPAS (MIPAS space) observations and with the model (model space) outputs and at three different levels: $121 \mathrm{hPa}$ (upper troposphere), $100 \mathrm{hPa}$ (tropopause) and $68 \mathrm{hPa}$ (lower stratosphere).

In the MLS space, the analyses behave consistently with the MLS observations from the upper troposphere to the lower stratosphere. In the model space, the analyses are wetter than the reference atmosphere as represented by ARPEGE and MLS in the upper troposphere $(121 \mathrm{hPa})$ and around the tropopause $(100 \mathrm{hPa})$, but are consistent with MLS and MIPAS in the lower stratosphere. In the MIPAS space, the sensitivity and the vertical resolution of the MIPAS data set at 121 and $100 \mathrm{hPa}$ prevent the assessment of the behaviour of the analyses particularly over intense convective areas as the South American, the African and the Maritime continents but, in the lower stratosphere $(68 \mathrm{hPa})$, the analyses are very consistent with MIPAS.

Two sensitivity studies are performed as follows. (1) We investigate the impact of some periods with no measurements onto the assimilated fields. We check that the background field tends to be redirected towards the free run, losing the memory of the MLS driving information injected into the assimilation system whatever the pressure considered. (2) We investigate the impact of using two versions of the MLS data (V3 and V4) on the assimilation fields, V4 showing an improvement in the cloud screening and first guess estimation compared to V3. In the tropical UTLS, the difference between the two analyses is significant, particularly over the convective areas in the upper troposphere/tropopause layer where the presence of clouds is prominent.

The analyses obtained from November 2011 (AugustOctober 2011 is considered as a spin-up period) to March 2013 are being used to assess the impact of the continental convective activity on the diurnal cycle of $\mathrm{H}_{2} \mathrm{O}$ in the tropical UTLS above the South American continent (Carminati et al., 2016) with a temporal resolution of $1 \mathrm{~h}$. The same methodology could be employed over the Indian Ocean, the Maritime Continent and the Tibetan Plateau to quantify the impact of the cyclone, the maritime convection and the conti- 
nental convection processes, respectively, on the $\mathrm{H}_{2} \mathrm{O}$ budget in the UTLS.

\section{Data availability}

The data used in this study were acquired as part of the activities of NASA's Science Mission Directorate and are archived and distributed by the Goddard Earth Sciences (GES) Data and Information Services Center (DISC) (http: //acdisc.gesdisc.eosdis.nasa.gov/data/Aura_MLS_Level2/).

Acknowledgements. The work was supported by the French Agence Nationale de la Recherche (ANR) TRO-pico project (http://www.univ-reims.fr/TRO-pico/). The provision of MIPAS data by ESA is gratefully acknowledged. We finally would like to thank the two anonymous reviewers for their fruitful comments.

Edited by: H. Worden

Reviewed by: two anonymous referees

\section{References}

Abida, R., Attié, J.-L., El Amraoui, L., Ricaud, P., Lahoz, W., Eskes, H., Segers, A., Curier, L., de Haan, J., Kujanpää, J., Nijhuis, A. O., Schuettemeyer, D., Tamminen, J., Timmermans, R., Veefkind, P., and Veihelmann, B.: Impact of Spaceborne Carbon Monoxide Observations from the S-5P platform on Tropospheric Composition Analyses and Forecasts, Atmos. Chem. Phys. Discuss., doi:10.5194/acp-2015-924, in review, 2016.

Bousserez, N., Attié, J.-L., Peuch, V.-H., Michou, M., Pfister, G., Edwards, D., Emmons, L., Mari, C., Barret, B., Arnold, S. R., Heckel, A., Richter, A., Schlager, H., Lewis, A., Avery, M., Sachse, G., Browell, E. V., and Hair, J. W.: Evaluation of the MOCAGE chemistry transport model during the ICARTT/ITOP experiment, J. Geophys. Res., 112, D10S42, doi:10.1029/2006JD007595, 2007.

Brewer, A. W.: Evidence for a world circulation provided by the measurements of helium and water vapour distribution in the stratosphere, Q. J. Roy. Meteor. Soc., 75, 351-363, 1949.

Carminati, F., Ricaud, P., Pommereau, J.-P., Rivière, E., Khaykin, S., Attié, J.-L., and Warner, J.: Impact of tropical land convection on the water vapour budget in the tropical tropopause layer, Atmos. Chem. Phys., 14, 6195-6211, doi:10.5194/acp-14-61952014, 2014.

Carminati, F., Ricaud, P., Pommereau, J.-P., D. Rivière, E., Attié, J.L., Payra, S., El Amraoui, L., and Abida, R.: Role of saturation in the water vapor diurnal cycle in the South American Tropical Tropopause Layer, Geophys. Res. Lett., in preparation, 2016.

Chauhan, S., Höpfner, M., Stiller, G. P., von Clarmann, T., Funke, B., Glatthor, N., Grabowski, U., Linden, A., Kellmann, S., Milz, M., Steck, T., Fischer, H., Froidevaux, L., Lambert, A., Santee, M. L., Schwartz, M., Read, W. G., and Livesey, N. J.: MIPAS reduced spectral resolution UTLS-1 mode measurements of temperature, $\mathrm{O} 3, \mathrm{HNO}_{3}, \mathrm{~N}_{2} \mathrm{O}, \mathrm{H}_{2} \mathrm{O}$ and relative humidity over ice: retrievals and comparison to MLS, Atmos. Meas. Tech., 2, 337353, doi:10.5194/amt-2-337-2009, 2009.
Claeyman, M., Attié, J.-L., Peuch, V.-H., El Amraoui, L., Lahoz, W. A., Josse, B., Ricaud, P., von Clarmann, T., Höpfner, M., Orphal, J., Flaud, J.-M., Edwards, D. P., Chance, K., Liu, X., Pasternak, F., and Cantié, R.: A geostationary thermal infrared sensor to monitor the lowermost troposphere: $\mathrm{O}_{3}$ and $\mathrm{CO}$ retrieval studies, Atmos. Meas. Tech., 4, 297-317, doi:10.5194/amt-4-297-2011, 2011.

Courtier, P., Freydier, C., Geleyn, J., Rabier, F., and Rochas, M.: The ARPEGE project at Meteo France, in: Atmospheric Models, 2, 193-231, Workshop on Numerical Methods, Reading, UK, 1991.

Dee, D. P., Uppala, S. M., Simmons, A. J., Berrisford, P., Poli, P., Kobayashi, S., Andrae, U., Balmaseda, M. A., Balsamo, G., Bauer, P., Bechtold, P., Beljaars, A. C. M., van de Berg, L., Bidlot, J., Bormann, N., Delsol, C., Dragani, R., Fuentes, M., Geer, A. J., Haimberger, L., Healy, S. B., Hersbach, H., Hólm, E. V., Isaksen, L., Kållberg, P., Köhler, M., Matricardi, M., McNally, A. P., Monge-Sanz, B. M., Morcrette, J.-J., Park, B.-K., Peubey, C., de Rosnay, P., Tavolato, C., Thépaut, J.-N., and Vitart, F.: The ERA-Interim reanalysis: configuration and performance of the data assimilation system, Q. J. Roy. Meteor. Soc., 137, 553-597, doi:10.1002/qj.828, 2011.

Durry, G., Amarouche, N., Joly, L., Liu, X., Parvitte, B., and Zéninari, V.: Laser diode spectroscopy of $\mathrm{H}_{2} \mathrm{O}$ at $2.63 \mu \mathrm{m}$ for atmospheric applications, Appl. Phys. B, 90, 573-580, 2008.

El Amraoui, L., Peuch, V.-H., Ricaud, P., Massart, S., Semane, N., Teyssédre, H., Cariolle, D., and Karcher,F.: Ozone loss in the 2002-2003 Arctic vortex deduced from the assimilation of Odin/SMR $\mathrm{O}_{3}$ and $\mathrm{N}_{2} \mathrm{O}$ measurements: $\mathrm{N}_{2} \mathrm{O}$ as a dynamical tracer, Q. J. Roy. Meteor. Soc., 134, 217-228, 2008.

El Amraoui, L., Attié, J.-L., Semane, N., Claeyman, M., Peuch, V.H., Warner, J., Ricaud, P., Cammas, J.-P., Piacentini, A., Josse, B., Cariolle, D., Massart, S., and Bencherif, H.: Midlatitude stratosphere - troposphere exchange as diagnosed by MLS $\mathrm{O}_{3}$ and MOPITT CO assimilated fields, Atmos. Chem. Phys., 10, 2175-2194, doi:10.5194/acp-10-2175-2010, 2010.

El Amraoui, L., Attié, J.-L., Ricaud, P., Lahoz, W. A., Piacentini, A., Peuch, V.-H., Warner, J. X., Abida, R., Barré, J., and Zbinden, R.: Tropospheric CO vertical profiles deduced from total columns using data assimilation: methodology and validation, Atmos. Meas. Tech., 7, 3035-3057, doi:10.5194/amt-73035-2014, 2014.

Emili, E., Barret, B., Massart, S., Le Flochmoen, E., Piacentini, A., El Amraoui, L., Pannekoucke, O., and Cariolle, D.: Combined assimilation of IASI and MLS observations to constrain tropospheric and stratospheric ozone in a global chemical transport model, Atmos. Chem. Phys., 14, 177-198, doi:10.5194/acp-14177-2014, 2014.

Fischer, H., Birk, M., Blom, C., Carli, B., Carlotti, M., von Clarmann, T., Delbouille, L., Dudhia, A., Ehhalt, D., Endemann, M., Flaud, J. M., Gessner, R., Kleinert, A., Koopman, R., Langen, J., López-Puertas, M., Mosner, P., Nett, H., Oelhaf, H., Perron, G., Remedios, J., Ridolfi, M., Stiller, G., and Zander, R.: MIPAS: an instrument for atmospheric and climate research, Atmos. Chem. Phys., 8, 2151-2188, doi:10.5194/acp-8-2151-2008, 2008.

Flentje, H., Dörnbrack, A., Fix, A., Ehret, G., and Hólm, E.: Evaluation of ECMWF water vapour fields by airborne differential absorption lidar measurements: a case study between Brazil and Europe, Atmos. Chem. Phys., 7, 5033-5042, doi:10.5194/acp-75033-2007, 2007. 
Hegglin, M. I., Gettelman, A., Hoor, P., Krichevsky, R., Manney, G. L., Pan, L. L., Son, S.-W., Stiller, G., Tilmes, S., Walker, K. A., Eyring, V., Shepherd, T. G., Waugh, D., Akiyoshi, H., Añel, J. A., Austin, J., Baumgaertner, A., Bekki, S., Braesicke, P., Brühl, C., Butchart, N., Chipperfield, M., Dameris, M., Dhomse, S., Frith, S., Garny, H., Hardiman, S. C., Jöckel, P., Kinnison, D. E., Lamarque, J. F., Mancini, E., Michou, M., Morgenstern, O., Nakamura, T., Olivié, D., Pawson, S., Pitari, G., Plummer, D. A., Pyle, J. A., Rozanov, E., Scinocca, J. F., Shibata, K., Smale, D., Teyssèdre, H., Tian, W., and Yamashita, Y.: Multimodel assessment of the upper troposphere, lower stratosphere: Extratropics, J. Geophys. Res., 115, D00M09, doi:10.1029/2010JD013884, 2010.

Hegglin, M. I., Plummer, D. A., Shepherd, T. G., Scinocca, J. F., Anderson, J., Froidevaux, L., Funke, B., Hurst, D., Rozanov, A., Urban, J., and von Clarmann, T.: Vertical structure of stratospheric water vapour trends derived from merged satellite data, Nat. Geosci., 7, 768-776, doi:10.1038/ngeo2236, 2014.

Hurst, D. F., Lambert, A., Read, W. G., Davis, S. M., Rosenlof, K. H., Hall, E. G., Jordan, A. F., and Oltmans, S. J.: Validation of Aura Microwave Limb Sounder stratospheric water vapor measurements by the NOAA frost point hygrometer, J. Geophys. Res.-Atmos., 119, 1612-1625, 2014.

Hurst, D. F., Rosenhof, K. H., Davis, S. M., Hall, E. G., Jordan, A. F., Read, W. G., Vömel, H., and Selkirk, H. B.: Water Vapor Measurement Biases in the TTL: MLS vs Frost Point Hygrometers, in: CT3LS meeting, Boulder, Colorado, 20-23 July 2015, available at: http://esrl.noaa.gov/csd/events/CT3LS/ presentations/wed-posters-4-hurst.pdf, 2015.

Ide, K., Courtier, P., Ghil, M., and Lorenc, A.: Unified notation for data assimilation: Operational, sequential and variational, J. Meteorol. Soc. Jpn., 75, 181-189, 1997.

IPCC: Intergovernmental Panel on Climate Change, Working Group I: The Physical Science Basis, 2.5.6 Tropospheric Water Vapour from Anthropogenic Sources, edited by: Solomon, S., Qin, D., Manning, M., Chen, Z., Marquis, M., Averyt, K. B., Tignor, M., and Miller, H. L., Cambridge University Press, 2007.

Jiang, J. H., Su, H., Pawson, S., Liu, H.-C., Read, W. G., Waters, J. W., Santee, M. L., Wu, D. L., Schwartz, M. J., Livesey, N. J., Lambert, A., Fuller, R. A., and Lee, J. N.: Five year (20042009) observations of upper tropospheric water vapor and cloud ice from MLS and comparisons with GEOS-5 analyses, J. Geophys. Res., 115, D15103, doi:10.1029/2009JD013256, 2010.

Jiang, J. H., Su, H., Zhai, C., Perun, V. S., Del Genio, A., Nazarenko, L. S., Donner, L. J., Horowitz, L., Seman, C., Cole, J., Gettelman, A., Ringer, M. A., Rotstayn, L., Jeffrey, S., Wu, T., Brient, F., Dufresne, J.-L., Kawai, H., Koshiro, T., Watanabe, M., Lécuyer, T. S., Volodin, E. M., Iversen, T., Drange, H., Mesquita, M. D. S., Read, W. G., Waters, J. W., Tian, B., Teixeira, J., and Stephens, G. L.: Evaluation of cloud and water vapor simulations in CMIP5 climate models using NASA “A-Train" satellite observations, J. Geophys. Res., 117, D14105, doi:10.1029/2011JD017237, 2012.

Jiang, J. H., Su, H., Zhai, C., Wu, L., Minschwaner, K., Molod, A. M., and Tompkins, A. M.: An assessment of upper troposphere and lower stratosphere water vapor in MERRA, MERRA2, and ECMWF reanalyses using Aura MLS observations, J. Geophys. Res.-Atmos., 120, 11468-11485, doi:10.1002/2015JD023752, 2015.
Kunz, A., Spelten, N., Konopka, P., Müller, R., Forbes, R. M., and Wernli, H.: Comparison of Fast In situ Stratospheric Hygrometer (FISH) measurements of water vapor in the upper troposphere and lower stratosphere (UTLS) with ECMWF (re)analysis data, Atmos. Chem. Phys., 14, 10803-10822, doi:10.5194/acp14-10803-2014, 2014.

Lahoz, W. A., Geer, A. J., Bekki, S., Bormann, N., Ceccherini, S., Elbern, H., Errera, Q., Eskes, H. J., Fonteyn, D., Jackson, D. R., Khattatov, B., Marchand, M., Massart, S., Peuch, V.-H., Rharmili, S., Ridolfi, M., Segers, A., Talagrand, O., Thornton, H. E., Vik, A. F., and von Clarmann, T.: The Assimilation of Envisat data (ASSET) project, Atmos. Chem. Phys., 7, 1773-1796, doi:10.5194/acp-7-1773-2007, 2007.

Lambert, A., Read, W. G., Livesey, N. J., Santee, M. L., Manney, G. L., Froidevaux, L., Wu, D. L., Schwartz, M. J., Pumphrey, H. C., Jimenez, C., Nedoluha, G. E., Cofield, R. E., Cuddy, D. T., Daffer, W. H., Drouin, B. J. , Fuller, R. A., Jarnot, R. F., Knosp, B. W., Pickett, H. M., Perun, V. S., Snyder, W. V., Stek, P. C., Thurstans, R. P., Wagner, P. A., Waters, J. W. , Jucks, K. W., Toon, G. C., Stachnik, R. A., Bernath, P. F., Boone, C. D., Walker, K. A., Urban, J., Murtagh, D., Elkins, J. W., and Atlas, E.: Validation of the Aura Microwave Limb Sounder middle atmosphere water vapor, nitrous oxide measurements, J. Geophys. Res., 112, D24S36, doi:10.1029/2007JD008724, 2007.

Liu, C. and Zipser, E. J.: Implications of the day versus night differences of water vapor, carbon monoxide, and thin cloud observations near the tropical tropopause, J. Geophys. Res., 114, D09303, doi:10.1029/2008JD011524, 2009.

Livesey, N. J., Read, W. G., Wagner, P. A., Froidevaux, L., Lambert, A., Manney, G. L., Millan Valle, L. F., Pumphrey, H. C., Santee, M. L., Schwartz, M. J., Wang, S., Fuller, R. A., Jarnot, R. F., Knosp, B. W., and Martinez, E.: Earth Observing System (EOS), Aura Microwave Limb Sounder (MLS), Version 4.2x Level 2 data quality and description document, Jet Propulsion Laboratory, California Institute of Technology, Pasadena, California, USA, available at: ttp://mls.jpl.nasa.gov/data/v4-2_data_ quality_document.pdf, 2015.

Livesey, N. J., Read, W. G., Froidevaux, L., Lambert, A., Manney, G. L., Pumphrey, H. C., Santee, M. L., Schwartz, M. J., Wang, S., Cofeld, R. E., Cuddy, D. T., Fuller, R. A., Jarnot, R. F., Jiang, J. H., Knosp, B. W., Stek, P. C., Wagner, P. A., and Wu, D. L.: Earth Observing System (EOS), Aura Microwave Limb Sounder (MLS), version 3.3 level 2 data quality and description document, Jet Propulsion Laboratory, California Institute of Technology, Pasadena, California, USA, available at: http: //mls.jpl.nasa.gov/data/v3-3_data_quality_document.pdf, 2011.

Luo, Z., Kley, D., Johnson, R. H., and Smit, H.: Ten years of measurements of tropical upper-tropospheric water vapor by MOZAIC - Part I: Climatology, variability, transport, and relation to deep convection, J. Climate, 20, 418-435, 2007.

Massart, S., Clerbaux, C., Cariolle, D., Piacentini, A., Turquety, S., and Hadji-Lazaro, J.: First steps towards the assimilation of IASI ozone data into the MOCAGE-PALM system, Atmos. Chem. Phys., 9, 5073-5091, doi:10.5194/acp-9-5073-2009, 2009.

Milz, M., von Clarmann, T., Fischer, H., Glatthor, N., Grabowski, U., Hopfner, M., Kellmann, S., Kiefer, M., Linden, A., Mengistu Tsidu, G., Steck, T., Stiller, G. P., Funke, B., Lopez-Puertas, M., and Koukouli, M. E.: Water Vapor Distributions Measured with the Michelson Interferometer for Passive Atmospheric Sound- 
ing on board Envisat (MIPAS/Envisat), J. Geophys. Res., 110, D24307, doi:10.1029/2005JD005973, 2005.

Oikonomou, E. K. and O'Neill, A.: Evaluation of ozone and water vapor fields from the ECMWF reanalysis ERA-40 during 1991-1999 in comparison with UARS satellite and MOZAIC aircraft observations, J. Geophys. Res.-Atmos., 111, D14109, doi:10.1029/2004JD005341, 2006.

Payra, S., Ricaud, P., Abida, R., Attié, J.-L., El Amraoui, L., Carminati, F., Rivière, E., Pommereau, J.-P., Khaykin, S.: Assimilation of water vapour measurements by a Chemistry Transport Model in the tropical UTLS, WWOSC, Montreal, Canada, August 2014.

Peuch, V. H., Amodei, M., Barthet, T., Cathala, M. L., Josse, B., Michou, M., and Simon, P.: MoCAGE, in: Modele de Chimie Atmosphérique aGrande Echelle, paper presented at the Workshop on Atmospheric Modelling, Météo France, Toulouse, France, 1999.

Randel, W. J. and Jensen, E. J.: Physical Processes in the tropical tropopause layer and Their roles in a changing climate, Nat. Geosci., 6, 169-176, 2013.

Randerson, J. T., van der Werf, G. R., Giglio, L., Collatz, G. J., and Kasibhatla, P. S.: Global Fire Emissions Database, Version 3 (GFEDv3.1), Data set, Oak Ridge National Laboratory Distributed Active Archive Center, Oak Ridge, Tennessee, USA, doi:10.3334/ORNLDAAC/1191, 2013.

Read, W. G., Lambert, A., Bacmeister, J., Cofield, R. E., Christensen, L. E., Cuddy, D. T., Daffer, W. H., Drouin, B. J., Fetzer, E., Froidevaux, L., Fuller, R., Herman, R., Jarnot, R. F., Jiang, J. H., Jiang, Y. B., Kelly, K., Knosp, B. W., Pumphrey, H. C., Rosenlof, K. H., Sabounchi, X., Santee, M. L., Schwartz, M. J., Snyder, W. V., Stek, P. C., Su, H., Takacs, L. L., Thurstans, R. P., Vomel, H., Wagner, P. A., Waters, J. W., Webster, C. R., Weinstock, E. M., and Wu, D. L.: Aura Microwave Limb Sounder upper tropospheric and lower stratospheric $\mathrm{H}_{2} \mathrm{O}$ and relative humidity with respect to ice validation, J. Geophys. Res., 112, D24S35, doi:10.1029/2007JD008752, 2007.

Ricaud, P., Sic, B., El Amraoui, L., Attié, J.-L., Zbinden, R., Huszar, P., Szopa, S., Parmentier, J., Jaidan, N., Michou, M., Abida, R., Carminati, F., Hauglustaine, D., August, T., Warner, J., Imasu, R., Saitoh, N., and Peuch, V.-H.: Impact of the Asian monsoon anticyclone on the variability of mid-to-upper tropospheric methane above the Mediterranean Basin, Atmos. Chem. Phys., 14, 1142711446, doi:10.5194/acp-14-11427-2014, 2014.

Schäfler, A., Dörnbrack, A., Kiemle, C., Rahm, S., and Wirth, M.: Tropospheric water vapor transport as determined from airborne lidar measurements, J. Atmos. Ocean. Tech., 27, 2017-2030, 2010.

Schiller, C., Grooß, J.-U., Konopka, P., Plöger, F., Silva dos Santos, F. H., and Spelten, N.: Hydration and dehydration at the tropical tropopause, Atmos. Chem. Phys., 9, 9647-9660, doi:10.5194/acp-9-9647-2009, 2009.

Seinfeld, J. H. and Pandis, S. N.: Atmospheric Chemistry and Physics: From Air Pollution to Climate Change, 2nd Edn., John Wiley \& Sons, New York, 2006.

Smith, R. N. B.: A scheme for predicting layer clouds and their water content in a general circulation model, Q. J. Roy. Meteor. Soc., 116, 435-460, 1990.

SPARC WAVAS: Upper tropospheric and stratospheric water vapour, edited by: Kley, D., Russell III, J. M., and Phillips, C., WMO/TD-No. 1043, SPARC Rep. No. 2, 2000.
SPARC CCMVal: SPARC report on the evaluation of chemistry climate models, edite by: Eyring, V., Shepherd, T. G., Waugh, D. W., SPARC Rep. No. 5, WCRP-132, WMO/TD-No. 1526, 2010.

Stiller, G. P., Kiefer, M., Eckert, E., von Clarmann, T., Kellmann, S., García-Comas, M., Funke, B., Leblanc, T., Fetzer, E., Froidevaux, L., Gomez, M., Hall, E., Hurst, D., Jordan, A., Kämpfer, N., Lambert, A., McDermid, I. S., McGee, T., Miloshevich, L., Nedoluha, G., Read, W., Schneider, M., Schwartz, M., Straub, C., Toon, G., Twigg, L. W., Walker, K., and Whiteman, D. N.: Validation of MIPAS IMK/IAA temperature, water vapor, and ozone profiles with MOHAVE-2009 campaign measurements, Atmos. Meas. Tech., 5, 289-320, doi:10.5194/amt-5-289-2012, 2012.

Tschanz, B., Straub, C., Scheiben, D., Walker, K. A., Stiller, G. P., and Kämpfer, N.: Validation of middle-atmospheric campaignbased water vapour measured by the ground-based microwave radiometer MIAWARA-C, Atmos. Meas. Tech., 6, 1725-1745, doi:10.5194/amt-6-1725-2013, 2013.

von Clarmann, T., Höpfner, M., Kellmann, S., Linden, A., Chauhan, S., Funke, B., Grabowski, U., Glatthor, N., Kiefer, M., Schieferdecker, T., Stiller, G. P., and Versick, S.: Retrieval of temperature, $\mathrm{H}_{2} \mathrm{O}, \mathrm{O}_{3}, \mathrm{HNO}_{3}, \mathrm{CH}_{4}, \mathrm{~N} 2 \mathrm{O}, \mathrm{ClONO}_{2}$ and $\mathrm{ClO}$ from MIPAS reduced resolution nominal mode limb emission measurements, Atmos. Meas. Tech., 2, 159-175, doi:10.5194/amt-2-159-2009, 2009.

Waters, J. W., Froidevaux, L., Harwood, R. S., Jarnot, R. F., Pickett, H. M., Read, W. G., Siegel, P. H., Cofield, R. E., Filipiak, M. J., Flower, D. A., Holden, J. R., Lau, G. K., Livesey, N. J., Manney, G. L., Pumphrey, H. C., Santee, M. L., Wu, D. L., Cuddy, D. T., Lay, R. R., Loo, M. S., Perun, V. S., Schwartz, M. J., Stek, P. C., Thurstans, R. P., Boyles, M. A., Chandra, K. M., Chavez, M. C., Chen, G. S., Chudasama, B. V., Dodge, R., Fuller, R. A., Girard, M. A., Jiang, J. H., Jiang, Y., Knosp, B. W., LaBelle, R. C., Lam, J. C., Lee, K. A., Miller, D., Oswald, J. E., Patel, N. C., Pukala, D. M., Quintero, O., Scaff, D. M., Van Snyder, W., Tope, M. C., Wagner, P. A., and Walch, M. J.: The Earth Observing System Microwave Limb Sounder (EOS MLS) on the Aura satellite, IEEE Trans. Geosci. Remote Sens., 44, 1075-1092, doi:10.1109/TGRS.2006.873771, 2006.

Weaver, A. and Courtier, P.: Correlation modelling on the sphere using a generalized diffusion equation, Q. J. Roy. Meteor. Soc., 127, 1815-1846, 2001.

Weinstock, E. M., Smith, J. B., Sayres, D. S. and Pittman, J. V. and Spackman, J. R. and Hintsa, E. J. and Hanisco, T. F. and Moyer, E. J. and St. Clair, J. M. and Sargent, M. R. and Anderson, J. G.: Validation of the Harvard Lyman- $\alpha$ in situ water vapor instrument: Implications for the mechanisms that control stratospheric water vapor, J. Geophys. Res., 114, D23301, doi:10.1029/2009JD012427, 2009.

Wetzel, G., Oelhaf, H., Berthet, G., Bracher, A., Cornacchia, C., Feist, D. G., Fischer, H., Fix, A., Iarlori, M., Kleinert, A., Lengel, A., Milz, M., Mona, L., Müller, S. C., Ovarlez, J., Pappalardo, G., Piccolo, C., Raspollini, P., Renard, J.-B., Rizi, V., Rohs, S., Schiller, C., Stiller, G., Weber, M., and Zhang, G.: Validation of MIPAS-ENVISAT $\mathrm{H}_{2} \mathrm{O}$ operational data collected between July 2002 and March 2004, Atmos. Chem. Phys., 13, 5791-5811, doi:10.5194/acp-13-5791-2013, 2013.

Yushkov, V., Merkulov, S., and Astakhov, V.: Optical balloon hygrometer for upper stratosphere and stratosphere water vapour measurements, in: Optical remote sensing of the atmosphere and 
clouds, edited by: Wang, J., Wu, B., Ogawa, T., and Guans, Z.-H., Proc. SPIE, 3501, 439-445, 1998.

Zöger, M., Afchine, A., Eicke, N., Gerhards, M. T., Klein, E., McKenna, D. S., Mörschel, U., Schmidt, U., Tan, V., Tuitjer, F., and Woyke, T.: Fast in situ stratospheric hygrometers: A new family of balloon-borne and airborne Lyman $\alpha$ photofragment fluorescence hygrometers, J. Geophys. Res.-Atmos., 104, 1807$1816,1999$. 